\title{
O DIREITO DA MÃE PRESA
}

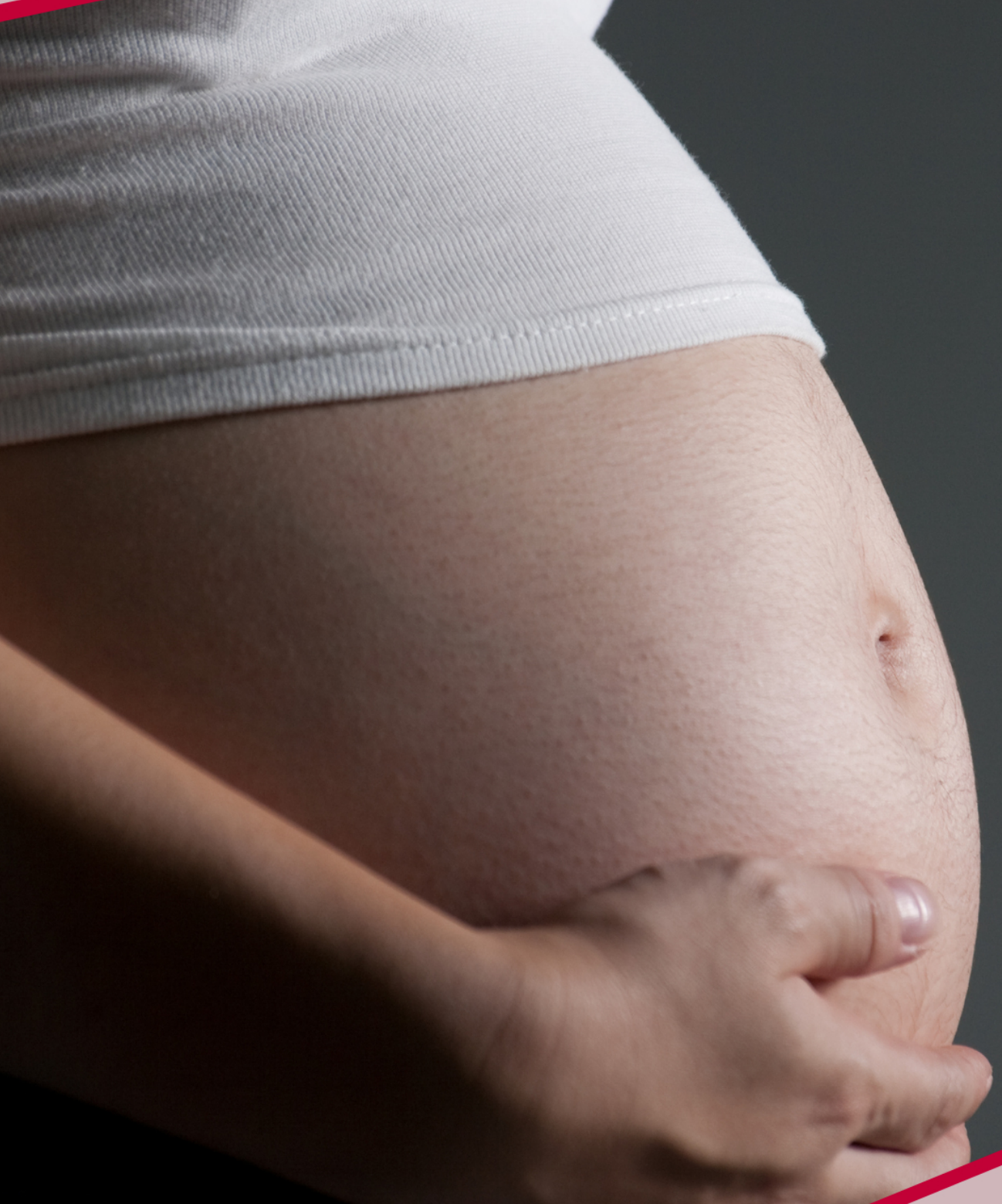

Caryna Rossafa Ferreira Claro Berbem 
Caryna Rossafa Ferreira Claro Berbem

O Direito Da Mãe Presa

$1^{\text {a }}$ ed.

Piracanjuba-GO

Editora Conhecimento Livre

Piracanjuba-GO 
$1^{\mathrm{a}} \mathrm{ed}$

\section{Dados Internacionais de Catalogação na Publicação (CIP)}

\section{Berbem, Caryna Rossafa Ferreira Claro \\ B233O O Direito Da Mãe Presa}

/ Caryna Rossafa Ferreira Claro Berbem. - Piracanjuba-GO

Editora Conhecimento Livre, 2021

55 f.: il

DOI: $10.37423 / 2021$. edcl 302

ISBN: 978-65-89955-23-8

Modo de acesso: World Wide Web

Incluir Bibliografia

1. mãe-presa 2. mulheres 3. direitos I. Berbem, Caryna Rossafa Ferreira Claro II. Título

CDU: 340

https://doi.org/10.37423/2021.edcl302

O conteúdo dos artigos e sua correção ortográfica são de responsabilidade exclusiva dos seus respectivos autores. 


\title{
EDITORA CONHECIMENTO LIVRE
}

\section{Corpo Editorial}

\author{
Dr. João Luís Ribeiro Ulhôa \\ Dra. Eyde Cristianne Saraiva-Bonatto \\ Dr. Anderson Reis de Sousa \\ MSc. Frederico Celestino Barbosa \\ MSc. Carlos Eduardo de Oliveira Gontijo
}

$\underline{\text { MSc. Plínio Ferreira Pires }}$

Editora Conhecimento Livre

Piracanjuba-GO 

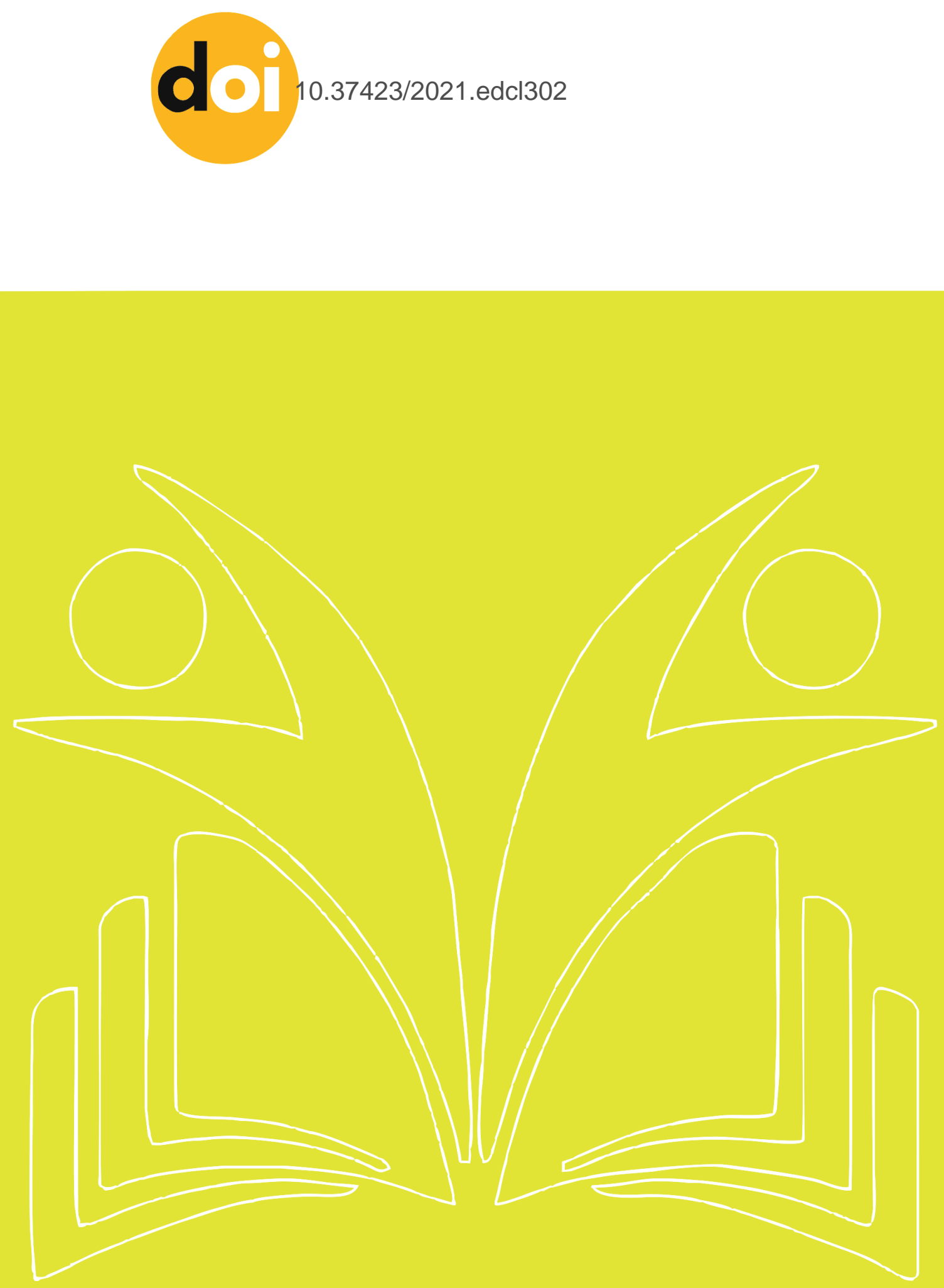
Dedico este trabalho exclusivamente a Deus e a minha família, obrigado por tudo! 
Agradeço primeiramente ao autor do universo por toda a sua bondade e misericórdia, pela benção concedida que é concluir este curso superior, mesmo em meio a tantas impossibilidades, as quais Ele me deu forças para vencer, pois para Ele não há nada impossível.

Agradeço a minha família mãe, pai e irmão por todo o amor e incentivo, e por compartilharem comigo o mesmo sentimento de conquista e superação.

Agradeço a todos os amigos que contribuíram de forma direta ou indireta para realização desse sonho.

E por fim, agradeço a esta universidade, seu corpo docente, bem como, a minha orientadora pelo suporte no pouco tempo que lhe coube, e a todos os demais professores que de forma significativa contribuíram para minha formação. 
"A justiça é o direito do mais fraco." Joseph Joubert 
Resumo: Este estudo tem como tema principal: o direito da mãe presa. O problema é: quais são os direitos garantidos da mãe presa e como é o encarceramento dessas mulheres? O objetivo é estudar as Leis sobre o direito da mãe da presa. Os objetivos específicos buscam estudar: o histórico dos direitos das mulheres; o ordenamento jurídico brasileiro; conhecer a Lei da Execução penal. Justificase em mostrar a luta das mulheres pelos seus direitos na sociedade, assim como contribuir para aprofundamento da pesquisa da temática no direito penal. O método do estudo é o método dedutivo, onde se realiza um levantamento dos principais direitos e garantias previstos no ordenamento jurídico às presas gestantes e mães. Relata a realidade da mãe presa e demonstra que as prisões brasileiras não garantem o pleno exercício da maternidade assegurados por Lei, mas nem sempre é assim. Conclui-se que há necessidade de adoção de medidas alternativas ao encarceramento melhorando as condições para a mãe presa e seus filhos, pois nem sempre são obedecidas as medidas levando em consideração o direito da mulher encarcerada.

Palavras-chave: Mãe presa. Mulheres. Direitos. 


\section{Sumário}

1. INTRODUÇÃO.

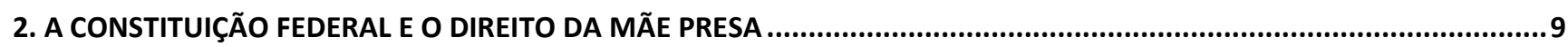

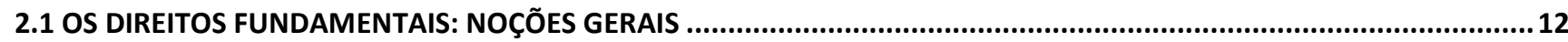

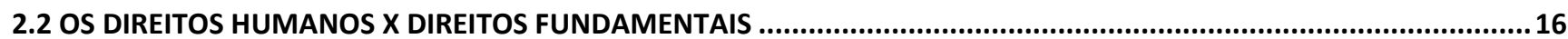

2.3 PRINCÍPIO DA DIGNIDADE DA PESSOA HUMANA E A PESSOA ENCARCERADA ...................................................20

2.3.1 DIREITO PENAL E OS DIREITOS FUNDAMENTAIS DAS MULHERES PRESAS (DIREITOS FUNDAMENTAIS COM

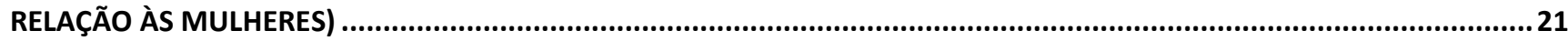

2.4 OS TRATADOS INTERNACIONAIS E A REGRA DE BANGKOK ..............................................................................23

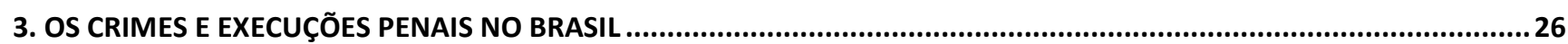

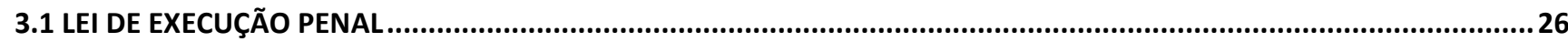

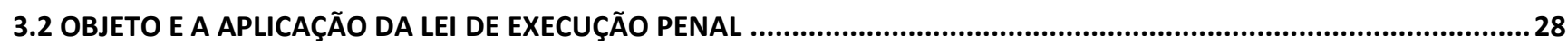

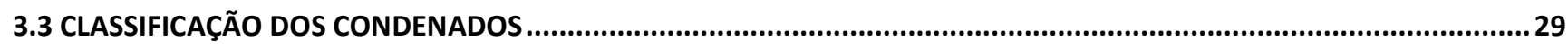

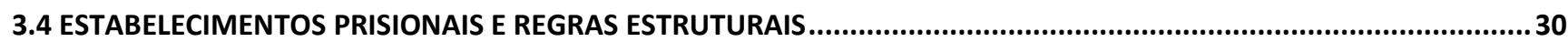

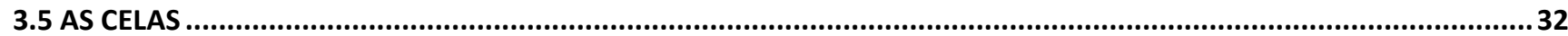

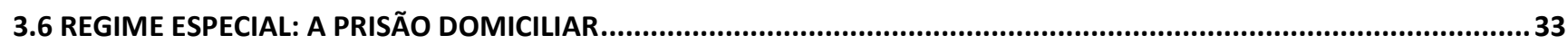

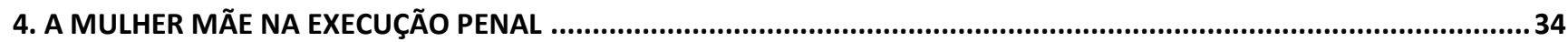

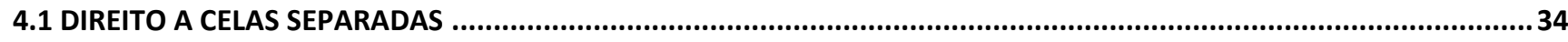

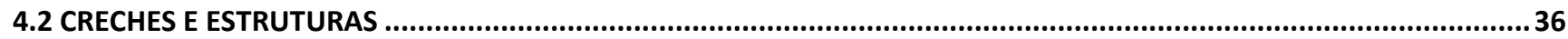

4.3 FILHOS E O ENCARCERAMENTO: DIREITO DA MATERNIDADE À MULHER ENCARCERADA .....................................38

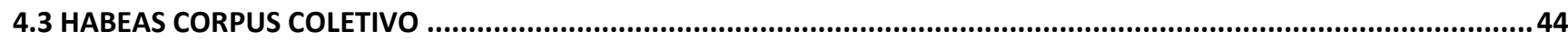

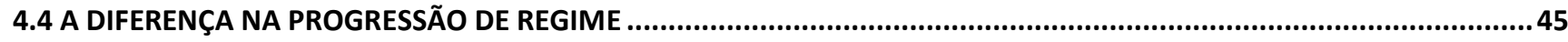

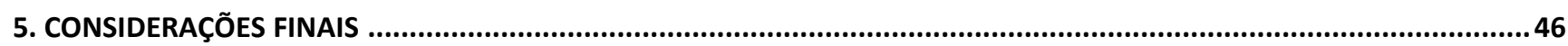

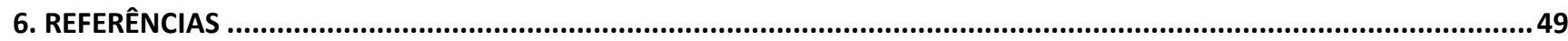




\section{INTRODUÇÃO}

Este estudo terá como temática principal “a Mãe Presa” Este tema possui grande relevância e um vasto desenvolvimento dos subtemas a serem analisados acerca do mesmo.

A problemática gira em torno do direito das mães presas, sendo assim fica a questão a ser estudada: quais são os direitos garantidos da mãe presa e como é o encarceramento dessas mulheres?

O objetivo dessa pesquisa é entender mais sobre os direitos das mulheres, mães presas, e relatar sobre as condições em que as mesmas e seus filhos são submetidos a viver dentro do encarceramento.

Os objetivos específicos são: estudar o histórico dos direitos das mulheres; compreender o ordenamento jurídico brasileiro acerca desses direitos; conhecer a Lei da Execução penal e seus subtemas de ligação.

A justificativa social é pautada no fato de que a mulher percorreu um longo caminho na luta por seus direitos, até conseguir chegar na realidade atual, onde ainda são incompletos seus direitos perante a sociedade. A importância acadêmica deste estudo visa a busca pela investigação do aprofundamento da temática em direito penal, pois tem-se que investigar, de um lado, aquilo que é adotado como critério discriminatório; de outro lado, cumpre verificar se há justificativa racional. A justificativa jurídica busca em sua relevância mostrar como um regime democrático e os interesses sociais e individuais podem contribuir para a construção de uma sociedade onde a mulher conquiste seus direitos e seja livre, igualitária, justa e solidária.

O método utilizado para realização da pesquisa foi o método dedutivo, que de acordo com Chaui (1997) consiste em um método de estudar os fatos a partir da verdade já conhecida, utilizando os autores como princípios do estudo.

Os autores apresentados foram: Bonini, Coelho, Alvarenga e diversas Leis e Artigos presentes na Constituição entre outros relevantes, comparando as ideias dos autores, em um aglomerado de informações relevantes e comparativas para enriquecer os conhecimentos da temática. Foi dado a preferência para artigos menos antigos.

No primeiro tópico a busca será pelo conhecimento da Constituição e direitos da mãe presa demonstrando a trajetória dessas conquistas através dos anos. Além disso, é preciso entender as noções gerais dos direitos fundamentais das mulheres, os direitos humanos, o Princípio da Dignidade 
da Pessoa Humana e a Pessoa Encarcerada. Será abordada também a relevância dos tratados internacionais e a Regra de Bangkok tudo ligado a mãe presa.

Dando sequência, o tópico 2 aborda a Lei de Execução Penal, definições, artigos importantes, objeto e a aplicação da Lei de Execução Penal, a classificação dos condenados, como são as condições dos estabelecimentos prisionais e regras estruturais da mãe encarcerada, como são as condições das celas e as condições para que a mulher possa cumprir a prisão domiciliar.

Para fechar o estudo apresenta-se o tópico 3, onde será abordado o fechamento em relação ao estudo da mulher presa. Será abordada a realidade da mulher, sendo mãe nas prisões, seus direitos, quais são os amparos para as mesmas dentro do sistema prisional de acordo com as Leis e os filhos no encarceramento e seus direitos. Por fim relata-se o habeas corpus coletivo e a diferença na progressão de regime.

Partiu-se da hipótese de que o estado tem condições de aplicar as Leis para que o sistema prisional possa contribuir para garantia dos direitos das mulheres presas assim como esse vínculo com os seus filhos dado de forma prazerosa é um método valioso para minimizar a repercussão negativa da prisão na vida afetiva dessas presas, tanto educacional quanto social na vida dos filhos, e poderá também ser um fator contributivo para reorganização do sistema familiar após o cumprimento da pena.

\section{A CONSTITUIÇÃO FEDERAL E O DIREITO DA MÃE PRESA}

Para dar início ao estudo primeiramente será apresentado a evolução dos principais direitos conquistados das mulheres previstos na Constituição Federal através dos anos. Segundo Bonini (2017) no Código Civil de 1916 mostra-se a relevância à mulher diante da sociedade, pois a mesma era considerada pela sociedade incapaz. Sendo vista como nível inferior a mulher necessitava de autorização do marido para que seus atos tivessem validade civil, mesmo no seio de sua família exercia o pátrio poder de forma subsidiária.

De acordo com Coelho (2017) a Constituição Federal e o Código Civil, durante décadas lutou para que as mulheres tivessem o seu lugar na sociedade, desde a Revolução Industrial, onde as mulheres começaram a ingressar no mercado de trabalho.

Ainda, segundo o supracitado, as mulheres conseguiram um pouco mais reconhecimento de seus direitos apenas a partir da década de 30, com a chegada da Era Vargas, conquistando seu espaço e garantindo o direito político ao voto. Um pouco mais tarde no ano de 1943 as mulheres ganharam 
espaço na CLT (Consolidação das Leis Trabalhistas), mas ainda assim precisavam da autorização de seus maridos para poder trabalhar fora.

Durante os anos seguintes, segundo Pierobom (2014), as mulheres lutaram por seus direitos no mercado de trabalho e no ano de 1988 com a Constituição da República e a Carta Magna conquistaram diversos direitos trabalhistas na CLT, em relação a licença maternidade e algumas garantias trabalhistas como, por exemplo, as empresas não poderiam mais exigir atestado de gravidez para contratação.

Em 2001 a mulher ganha em poder familiar, capacidade civil plena, igualdade de direitos civis. Em 2006, a Lei $n^{\circ} 11.340$, conhecida como Maria da Penha, garantiu o direito de apoio e assistência a mulher vítima da violência. Em 2019 a Lei n 12.034 ampliou o direito à participação da mulher na política que já havia sido conquistado com a Era Vargas. Em 2015 a Lei n 13.104, instituiu no Código Civil o crime de Feminicídio. (COELHO, 2017)

O primeiro inciso do artigo 5으 da Constituição Federal traz em relação ao direito das mulheres o que conhecemos por "igualdade de gênero". Isto é, prevê que todos os indivíduos, independentemente do gênero, são pessoas iguais sob a visão da Constituição Federal. Significa que todos devem e podem ter os mesmos direitos, oportunidades, responsabilidades e as mesmas obrigações. O inciso é importante sendo considerado um relevante direito fundamental, imprescindível à cidadania, à sociedade e ao Estado brasileiro, e foi dessa maneira, advindo desse artigo que se iniciaram as conquistas das mulheres nos dias atuais. (TAVASSI E MORAIS, 2019)

Essa igualdade, segundo Tavassi e Morais (2019), deve ser formal, garantindo assim que todos os indivíduos da sociedade, residentes no país, recebam o mesmo tratamento perante a lei, de forma igualitária, que irá demonstrar a forma com que as pessoas têm suas particularidades e são diferentes entre si, e que essas diferenças e particularidades devem estar em contato da sua busca de respeito de forma balanceada.

A igualdade de gênero, tem sua concretização se por meio de políticas públicas adequadas e legislação, que todos e principalmente o Estado, possam garantir a todas as mulheres independentemente de sua origem, cor, classe social ou orientação sexual as oportunidades e direitos que são necessários para que elas possam se desenvolver por igual na sociedade. (SANTOS e OLIVEIRA, 2010)

Segundo Rodriguez (2016), conforme visto pelo breve contexto histórico acima em relação ao direito das mulheres, o patriarcado sempre desprezou-as colocando em uma posição socialmente inferior, de 
submissão, circunstância. As conquistas foram aos poucos, e em diversas áreas como por exemplo no âmbito familiar, pois antigamente a figura masculina era vista como o chefe da relação, hoje vemos que isso já está ultrapassado, sendo visto como ambos os chefes da relação.

Ramos (2012) afirma também que a opressão masculina se estendeu por séculos nesse contexto sendo que a mulher é considerada, não só pelos homens, mas também pela sociedade, pela religião e pela legislação como um objeto não podendo ter vontades próprias.

Ser homem, inserido na cultural patriarcal, significa possuir, dominar, delimitar território e ter controle sobre ele, e dentro deste contexto o corpo da mulher é mais um objeto que pertence ao homem e deve ser controlado. (NARVAZ E KOLLER, 2006)

Visto o contexto acima, pode-se afirmar que tudo que está ligado à violência contra a mulher está ligada diretamente com o patriarcado, pois, há hierarquização social dos sexos, onde o gênero masculino é tido infelizmente como o gênero dominante na sociedade. Sendo assim, a mulher não é vista com igualdade em relação ao homem, desde os primórdios da humanidade a mesma é tida e vista como propriedade privada do mesmo.

(...) o papel social, e logo jurídico, designado à mulher é de inferioridade em relação ao homem. No direito privado, está sempre sujeita à potestas alheia: à pátria potestas, se filiafamilias; normalmente à manus do marido, se esposa; e à tutela perpétua, se sui iuris. Não pode ser tutora de impúberes e adotar filhos; testemunhar um testamento; garantir obrigações de homens (intercedere pro allis). No âmbito do direito público não é diferente: a mulher não participava da res pública, desempenhando funções de caráter público: não pode, exercer uma magistratura nem postulare pro allis perante o magistrado. A capacidade de fato se dava aos 25 anos, antes disso e após os 14 anos havia um período de curatela. As mulheres, no entanto, estavam sempre sob tutela. Elas eram consideradas incapazes para a prática dos atos da vida civil; necessitavam, sempre, de um tutor que lhes representasse os direitos na sociedade romana (tutela perpétua). Jamais podiam ocupar qualquer cargo público. (PINHO, 2002, p.199)

Gayón (2010) afirma que as práticas de atos violentos contra as mulheres são praticados no mundo inteiro, sendo que seu início foi no século XV, desde quando tinham que conquistar territórios através das grandes navegações sendo que na América Latina os crimes de violência eram praticados pelos navegadores europeus que violentavam as mulheres nativas das terras conquistadas.

Para Gayón (2010), aquelas mulheres que vivem sozinhas, são mães solteiras, imigrantes, jovens trabalhadoras, são aquelas mais propícias a se tornarem vítimas da sociedade, não pelo fato de ser mais vulneráveis que as demais, mas pelo fato da personificação das mudanças que vêm ocorrendo na sociedade culturalmente patriarcal. 
Pode-se afirmar, portanto, que a mulher, com certeza, tem desempenhado e lutado por seu papel, que percorreu um caminho permitindo assim, que contasse o Brasil hoje com doutoras, com mulheres em diversas áreas e espaços, que até poucas décadas eram exclusivos do homem e hoje foram conquistados. (COELHO, 2017)

Bijos (2006, p. 247), cita com bastante conviç̧ão que: "as mulheres cada vez mais se constituem em população ocupada e seus níveis de escolaridade superam os masculinos".

Ou seja, é possível afirmar que as mulheres estão cada dia mais ocupando seus espaços na sociedade de maneira satisfatória, é necessário entender os direitos fundamentais das mesmas, que é o assunto sequente.

Apesar dos avanços e transformações até a atualidade caminham a passos lentos, depende de realizações conjunturais em educação, saúde, trabalho, de guarida estatal e implementação de cada cidadão.

Ações como cotas, programas de conscientização, políticas públicas são peças de um quebra-cabeças de enormes proporções.

E o avanço ainda é lento pela luta dos seus direitos. Há retrocessos, estagnação entre perdas e ganhos de seus direitos fundamentais, conforme relatado na próxima discussão.

\subsection{OS DIREITOS FUNDAMENTAIS: NOÇÕES GERAIS}

Segundo Bastos (2018), os direitos e garantias fundamentais são direitos garantidos para todos os indivíduos na sociedade atual, enquanto sendo pessoas de direito. São, portanto, garantias que foram formalizadas a longo prazo de tempo, específicos aos seres humanos. E, por isso, estão ligados às perspectivas de direitos humanos.

Com o avanço das sociedades jurídicas, os direitos e garantias fundamentais e os preceitos conquistados deram a entender que são o conjunto de preceitos, que são hoje positivados. Com a formalização da Constituição Federal de 1988, veio a refletir desta forma o que já tinha sido estabelecido na Carta de Direitos Humanos de 1948. Trazendo o que chamamos de direitos e garantias que são classificados como fundamentais para obter a manutenção do ordenamento jurídico. (BASTOS, 2018) 
Gomes (2015) definem o conceito de direitos fundamentais como direitos essenciais à vida digna e respeitante à pessoa humana. Sendo puro e simplesmente do Estado o dever de dar essa proteção. Porém, os direitos fundamentais, têm alguns atributos próprios.

Os atributos dos direitos fundamentais são: Universalidade; Indivisibilidade; Interdependência; Interrelacionaridade; Imprescritibilidade; Inalienabilidade; Historicidade; Irrenunciabilidade; Vedação ao retrocesso; Limitabilidade ou relatividade; Inviolabilidade; Concorrência; Complementaridade; Aplicabilidade imediata e Constitucionalização.

Segundo Bastos (2018), a universalidade trata dos direitos e garantias fundamentais que se vinculam no princípio da liberdade, vindo da dignidade da pessoa humana, devendo possuir como sujeito ativo, independente de crença, nacionalidade, política, raça, podendo ser pleiteado em qualquer foro internacional ou nacional. $A$ indivisibilidade relata que os direitos compõem um único conjunto dos direitos, não podendo ser analisado de forma separada, onde se houver uma forma de desrespeito a apenas um desses direitos, irá constituir uma violação de todos.

Ainda o supracitado afirma que a Interdependência são vinculados uns aos outros, não sendo enxergados como direitos distintos, um bloco que irá apresentar interpenetrações. A liberdade de locomoção estará relacionada à garantia de ter o Habeas Corpus e ao devido processo legal.

De acordo com Mendes (2016) a Interrelacionaridade são aqueles mecanismos para assegurar a inviolabilidade dos direitos e garantias fundamentais que passaram a ter abrangência regional e mundial. Sendo assim, o indivíduo optar por qual âmbito de proteção deseja para garantir que seu direito não seja violado.

Já a Imprescritibilidade determina que os direitos fundamentais não irão se declinar com o tempo, não irão prescrever, sendo sempre exercidos e exercíveis. A Inalienabilidade demonstra que esses direitos como não produzem conteúdos econômicos patrimoniais, não são transferíveis, nem são negociáveis e disponíveis, não podendo estar em comércio, limitando - se ao princípio da autonomia privada. (BASTOS, 2018)

Sampaio (2014) relata que a historicidade vem da forma como eles foram criados, já que não nasceram todos de uma única vez, e gradativamente foram se tornando frutos da evolução e desenvolvimento histórico cultural. Ainda, de acordo com o supracitado, a Irrenunciabilidade demonstra que esses direitos não podem ser renunciados por quem está em posse de sua titularidade, não podendo fazer 
deles o que quiser, pois irá influenciar e modificar todo o conjunto, e não somente a um único indivíduo.

De acordo com Fernandes (2019) a vedação ao retrocesso não pode visar a limitação ou diminuição, sendo como critério principal a legitimidade de conteúdo constitucional. A característica maior consiste em impedir a revogação das normas que são garantidoras de direitos fundamentais e impedir que haja a implantação das políticas públicas para o enfraquecimento desses direitos. Limitabilidade ou relatividade consiste na forma que nenhum direito fundamental poderá ser considerado absoluto, porém esses direitos deverão ser aplicados e interpretados sendo levados em consideração as formas jurídicas existentes e seus limites fáticos.

Bastos (2018) afirma que a inviolabilidade vem para mostrar que não ha possibilidade desses direitos não serem enxergados por suas disposições infraconstitucionais ou pelos atos das autoridades públicas. A complementaridade define que esses direitos podem e devem ser interpretados em conjunto, para que não haja hierarquia entre eles.

Segundo Taufick (2014) concorrência é a atribuição que se dá para que possam ser exercidos concentradamente pelo mesmo sujeito ativo. Por isso a aplicabilidade imediata elenca que todas as normas que definem os direitos e garantias fundamentais terão aplicação imediata, e somente caberá aos três poderes públicos, que são eles: o Legislativo, Judiciário e Executivo fazer o desenvolvimento dos direitos.

O que o supracitado quis dizer é que quem melhor para aplicar os direitos e garantias fundamentais do cidadão, principalmente das mulheres, senão os principais poderes que são o Legislativo, Judiciário e Executivo que juntos formam uma força enorme para o país.

Já Bastos (2018) entende que os direitos fundamentais advêm de uma construção que não é atual, mas sim histórica, ou seja, a luta não é de hoje. Além de serem irrenunciáveis, isto significa que, todos têm direito e ninguém poderá recusá-los, na forma de que são inerentes. Sendo assim, nenhum desses direitos podem ser trocados, violados, vendidos ou disponibilizados, correndo o risco de haver punição do Estado.

Ademais, esses direitos não são direitos atingidos pela prescrição e podem ser exigidos a qualquer momento. Os mesmos podem ser aplicados indistintamente a todos os indivíduos.

Os direitos e garantias fundamentais estão no dispositivo da Constituição Federal de 1988, em seu Título II. Enquanto os direitos fundamentais se referem aos direitos propriamente ditos que estão na 
Constituição, as garantias fundamentais se referem a medidas previstas e visam a proteção desses direitos. Portanto, são exemplos de direitos fundamentais o direito à vida e à liberdade. E são exemplos de garantias fundamentais o Habeas Corpus e o Habeas Data, além de outros fundamentos e formas jurídicas. (ALVARENGA, 2020)

O que os supracitados deixam claro é que a Constituição tem o dever de assegurar o direito à vida e a liberdade para todos os cidadãos, e a luta pelo reconhecimento desses direitos em relação ao sexo feminino foi ainda maior, protegendo seus direitos que podem ser exigidos a qualquer momento.

O artigo 5ㅇ da Constituição Federal vem para apresentar as garantias e direitos que são imprescindíveis e fundamentais a uma digna vida humana. Porém, o caput do artigo vem para nos apresentar os 5 direitos que são de suma importância e são fundamentais para o ordenamento jurídico. (BRASIL, 2016) Assim, nos é dado o artigo: Art. 5o Todos são iguais perante a lei, sem distinção de qualquer natureza, garantindo-se aos brasileiros e aos estrangeiros residentes no País a inviolabilidade do direito à vida, à liberdade, à igualdade, à segurança e à propriedade [...]

Assim, são direitos fundamentais o Direito à vida; Direito à igualdade; à liberdade; à segurança; e à propriedade. $\mathrm{O}$ direito à vida vem para definir não somente o direito de nascer e existir, mas também de ter um modo digno de vida, e principalmente não ferir a integridade moral e física. $\mathrm{O}$ direito à liberdade, visa ao indivíduo seu direito de ir e vir tendo sua liberdade de se expressar como quiser, ter sua crença, sua religião e ser resguardado caso não haja quem concorde. O direito à igualdade, vem como um resguardo para a discriminação. Porém, deve ser levado em consideração e visto de diferentes formas no ordenamento jurídico, pois pode ser uma igualdade material ou formal. (BASTOS, 2014)

Segundo Cavalcante (2007), o Estado terá o direito de punir, mas sempre com a visão de proteger os indivíduos, o que acarreta no direito à segurança. Sendo assim, deixa claro que nenhum indivíduo possa ser punido por algum fato que não esteja com previsão na Lei.

Enfim, o direito à propriedade, sendo uma forma de direitos que todo tem, a Constituição vem para prever também que esse direito a propriedade deve atender ao princípio da função social. 


\subsection{OS DIREITOS HUMANOS X DIREITOS FUNDAMENTAIS}

Para começo de estudo acerca desses direitos, deve-se em primeiro passo analisar a diferença dos direitos humanos e os direitos fundamentais, são quem são os principais direitos do cidadão e destinatários de cada proteção.

Os Direitos Humanos são garantias que são totalmente para a existência da pessoa humana, como o direito à vida, a liberdade, a liberdade de expressão e opinião, direito a trabalho, a educação, saúde, e muitos outros sem que haja discriminação, independentemente de sua raça, nacionalidade, etnia, sexo, religião, sendo intransmissíveis, não podendo nenhum indivíduo ser privado desses direitos.

Segundo Piovesan (2004) os Direitos Humanos não nasceram todos de uma vez e estão em constante processo de construção e reconstrução, adaptando-se sempre a cada ano que passa. Segundo a Declaração Universal de Direitos Humanos, de 1948, o conceito de Direitos Humanos é consequência da recente "internacionalização dos direitos humanos, surgido no pós-guerra, como resposta às atrocidades e aos horrores cometidos pelo regime nazista" que traz o Estado como sendo o grande violador de direitos humanos.

Porém esses direitos podem ser limitados caso aconteçam em situações que sejam específicas, como por exemplo: uma pessoa não ter seu direito de liberdade por ser considerada culpada de um crime diante de um tribunal, e devidamente com o processo legal.

De acordo com Ramos (2012) desde 1945, com a Carta de São Francisco, e posteriormente com a Declaração Universal dos Direitos Humanos, de 1948, foram criadas dezenas de tratados e convenções dedicados à preocupação internacional com a proteção dos direitos fundamentais de todos os indivíduos, sem qualquer distinção.

Os Direitos Humanos são caracterizados pela universalidade e indivisibilidade dos direitos fundamentais dos indivíduos, são universais, pois destinam-se a todos os seres humanos sem distinção, sob a crença de que a condição de pessoa é o requisito único para a titularidade de direitos, considerando o ser humano como um ser essencialmente moral, dotado de unicidade existencial e dignidade.

A garantia dos direitos civis e políticos é condição para a observância dos direitos sociais, econômicos e culturais - e vice-versa. Quando um deles é violado, os demais também o são, portanto os direitos devem ser respeitados em sua totalidade, o que caracteriza a indivisibilidade dos Direitos Humanos. 
Dessa forma, entende-se que todos os direitos humanos são universais, interdependentes e interrelacionados. A comunidade internacional deve tratar os direitos humanos globalmente de forma justa e equitativa, em pé de igualdade e com a mesma ênfase. (PIOVESAN, 2004)

Sobre isso, o direito internacional dos Direitos Humanos coloca a importância de atores estatais e nãoestatais em preocupar-se com o modo como os indivíduos são tratados dentro dos Estados, desta forma, a proteção da dignidade e integridade dos indivíduos não é somente responsabilidade exclusiva da jurisdição doméstica de cada Estado internamente, mas uma responsabilidade de todos, Estados ou não.

Piovesan (2004), relata ainda que a internacionalização desses direitos e sua proteção tem consequências na noção tradicional de que o Estado possui soberania absoluta, visto que ao admitir intervenções de órgão internacionais no ordenamento jurídico interno em prol da proteção dos Direitos Humanos o Estado passa por um processo de relativização da soberania.

Outra consequência é assumir o indivíduo como sendo um sujeito de direito internacional, juntamente com Estados e organismos internacionais, e que por essa razão deve ter direitos protegidos na esfera internacional.

Ao assumir outros atores internacionais além dos Estados, é importante que se democratize o sistema internacional, em especial os Direitos Humanos, visto isso algumas Cortes de direito internacional em matéria de Direitos Humanos permite que o indivíduo, agora aceito como um ator do sistema internacional, tenha acesso ao direito internacionalmente por meio de petições individuais, ou seja, uma pessoa física comum pode, por direito, ter acesso à justiça internacional sem mediação estatal, ou até mesmo fazer denúncias ao Estado violador de Direitos Humanos, por exemplo.

Boaventura apud Piovesan (2004) afirmou que o sistema internacional de proteção de Direitos Humanos é integrado por tratados internacionais de proteção, que buscam um consenso internacional acerca de princípios básicos de proteção a serem adotados segundo a consciência ética compartilhada pelos Estados partes desses instrumentos de direito internacional.

Esse sistema internacional é constituído pelo sistema normativo global de proteção desses direitos e por sistemas regionais, que por sua vez buscam internacionalizar os direitos humanos no âmbito regional.

Portanto, os dois sistemas, global e regional, baseiam-se nos princípios da Declaração Universal de Direitos Humanos, complementando-se ao interagir com o sistema nacional de proteção, com a 
finalidade de proporcionar a maior efetividade possível na proteção e promoção dos direitos humanos internamente.

A proteção dos Direitos Humanos seja efetiva são necessárias políticas universais, mas também específicas, voltadas a grupos socialmente vulneráveis, ou seja, "a implementação dos direitos humanos requer a universalidade e a indivisibilidade desses direitos, acrescidas do valor da diversidade". (PIOVESAN, 2004, p.18)

Determinados sujeitos de direito e/ou violações exigem uma resposta específica e diferenciada de acordo com a necessidade, dessa forma mulheres, crianças, afrodescendentes, migrantes, pessoas portadoras de deficiência, dentre outras categorias vulneráveis, devem ser vistas dentro das especificidades e peculiaridades de sua condição social, em outras palavras.

Piovesan (2004) apud Boaventura afirma que:

Temos o direito a ser iguais quando nossa diferença nos inferioriza; e temos o direito a ser diferentes quando nossa igualdade nos descaracteriza. Daí a necessidade de uma igualdade que reconheça as diferenças e de uma diferença que não produza, alimente ou reproduza as desigualdades. (PIOVESAN, 2004, p. 17)

Promover a garantia efetiva dos direitos fundamentais, econômicos, sociais e culturais, é uma obrigação moral e jurídica dos Estados, fundamentada em tratados de proteção dos Direitos Humanos dos quais são partes signatárias, visto isto, o Estado tem o dever de respeitar, proteger e implementar tais direitos em seu ordenamento jurídico interno, além de garantir a aplicação dos mesmos, pois não é admissível que os Estados aceitem direitos, por meio de tratados internacionais onde se comprometem a assumir as responsabilidade ali estabelecidas, e neguem as garantias de sua proteção internamente, aquém do compromisso assumido. (RAMOS, 2012)

Alonso (2011) relata que o Estado é uma organização de unidade política detentora da força e capaz de sobrepor-se a agressividade e ao egoísmo do ser humano, garantindo, amparado pela Soberania, os Direitos Fundamentais do povo, como os direitos de liberdade civil, pessoal, política e econômica. Ou seja, o Estado é uma organização de grande poder e tem uma relevância enorme nas conquistas dos direitos das mulheres.

Já Dalari (1998 p.29) explica que o Estado é, também, uma pessoa jurídica de direito público internacional e o que o diferencia das demais é que apenas o Estado possui Soberania, tanto que para que uma sociedade política seja reconhecida pelos demais Estados como sendo um Estado de fato, 
essa sociedade política deve ter "condições de assegurar o máximo de eficácia para sua ordenação num determinado território e que isso ocorra de maneira permanente".

Sobre o supracitado o reconhecimento, entretanto, não é um elemento crucial para a formação de um Estado desde que este apresente todas as características comuns aos Estados (Soberania, Território e Povo) e tenha viabilidade, conseguindo agir com independência e manter, inteiramente, uma ordem jurídica eficaz.

Ramos (2012) afirma que o Estado, ao assinar e ratificar um tratado internacional de proteção de Direitos Humanos assume a responsabilidade de respeitar e garantir os direitos estabelecidos nestes acordos internacionais. Declarar e fundamentar os direitos humanos não é mais um problema, mas protegê-los e programá-los de forma efetiva internamente.

Para Alonso (2011) determinar uma origem para Estado que satisfaça a todas as correntes teóricas é quase impossível, as correntes teóricas defendem diferentes origens do Estado, há quem acredite que o Estado sempre existiu e há quem acredite que o mesmo nasceu no século XVI, quando o termo Estado, indicando uma sociedade política, apareceu pela primeira vez em “O Príncipe” de Maquiavel.

Entretanto de acordo com Dalari (1998) é difícil definir um momento histórico específico do nascimento do Estado, tendo em vista que este é um produto de um lento processo de acontecimentos históricos.

O homem é um animal social e é sabido que desde que habita a Terra encontra-se integrado em organizações sociais, providas de poder e com autoridade para determinar normas sociais e o comportamento do grupo, por esta razão, há autores que acreditem que o Estado nasceu junto às primeiras sociedades.

Diversos outros autores afirmam que a sociedade existiu antes da criação do Estado e este foi estabelecido posteriormente, com o objetivo de atender a necessidades ou conveniências dessas sociedades já existentes. Contradizendo estas duas últimas vertentes, há autores que admitam como Estado as sociedades políticas dotadas de características definidas, e que o Estado é um conceito histórico concreto que nasce junto a ideia e a prática da soberania, o que só ocorrem no século XVII.

Quanto à formação originária do Estado há teorias que afirmam que os Estados surgiram de forma natural e espontânea, sem que houvesse uma causa comum entre os

diferentes Estados. Há as teorias contratualistas, que defendem que o Estado se formou a partir da vontade dos indivíduos que, vivendo em estado de natureza sentiram a necessidade de segurança e 
proteção dos seus bens privados, concordaram em passar parte de sua autonomia e soberania à uma instituição que promoveria o bem-estar e a segurança dos indivíduos de forma legítima e legal, por meio de um contrato social.

Segundo Oliveira (2016) das teorias não-contratualistas, as principais teorias defendem a origem familiar ou patriarcal, onde cada família primitiva se ampliou e deu origem a um Estado; a origem por atos de força, violência ou conquista; a origem em causas econômicas ou patrimoniais, onde "um Estado nasce das necessidades dos homens; ninguém basta a si mesmo, mas todos nós precisamos de muitas coisas" como defendeu Platão em "A República"; e a origem no desenvolvimento interno da sociedade, onde acredita-se que o Estado nasce das sociedades que atingem um maior grau de desenvolvimento complexidade.

\subsection{PRINCÍPIO DA DIGNIDADE DA PESSOA HUMANA E A PESSOA ENCARCERADA}

O princípio da dignidade da pessoa humana está previsto no artigo $1^{\circ}$, inciso III, da Constituição Federal. “A República Federativa do Brasil, formada pela união indissolúvel dos Estados e Municípios e do Distrito Federal, constitui-se em Estado Democrático de Direito e tem como fundamentos: III- A dignidade da pessoa humana".

Sarlet (2001) afirma que a dignidade da pessoa humana é irrenunciável e a qualifica afirmando que ela existe ainda que o Direito não a reconheça. Entretanto, a ordem jurídica promove importante papel prevendo-a, promovendo-a e protegendo-a.

Desta forma, a dignidade da pessoa humana é um direito inviolável que no âmbito familiar deve ser efetivado pela própria família, pela sociedade e pelo Estado, para que as crianças e os adolescentes possam ter o mínimo de dignidade assegurada.

Ou seja, em relação a esse princípio é conferido a estes o dever de respeitar e proteger os direitos fundamentais dessas pessoas destinatárias de tutela especial. "A família, base da sociedade, tem especial proteção do Estado" (CONSTITUIÇÃO FEDERAL, 1988. Art.226)

O princípio da Dignidade da Pessoa Humana representa o epicentro axiológico da ordem constitucional, irradiando efeitos sobre todo o ordenamento jurídico, não apenas no que tange aos atos e às situações envolvendo a esfera pública dos atos estatais, mas também todo o conjunto das relações privadas que se verificam no âmbito da sociedade. No âmbito do planejamento familiar, o principio em tela deve não somente ser aplicado no sentido de garantir o exercício desse direito pelo casal, como também na proteção daquele que poderá vir a nascer, e o conflito entre essas duas perspectivas deve ser solucionado, em regra, em favor desse último (GAMA, 2008). 
De acordo com Soder (1960), a dignidade é essência do ser humano, e não simplesmente um direito, pois ela "concede unidade aos direitos e garantias fundamentais, sendo inerente às personalidades humanas" (MORAES, 2006, p.16)

Schmidt (2007) retrata que o direito da pessoa encarcerada é ser tratada com dignidade, eis que esta é garantida também a qualquer uma pessoa, independentemente da situação fática peculiar que surgir em sua vida. Ao perder a liberdade, todos os outros direitos permanecem, devendo o encarcerado, por isso, ser tratado com um respeito inviolável, o qual deve nortear toda a atividade jurisdicional.

Sabe-se que com os efeitos da condenação previstos na Constituição Federal e a Lei infraconstitucional, o condenado mantém todos os direitos que lhe assistiam antes da sentença condenatória, ou seja, seus direitos são os mesmos.

Segundo Nunes (2019) embora exista uma grande e ampla proteção aos direitos humanos e dignidade da pessoa humana da população carcerária, inclusive feminina, sua aplicação não é efetiva principalmente nas prisões femininas.

E porque isso acontece? Geralmente isso se dá pelo fato de que a prisão é entendida na sociedade como um ambiente para punir a pessoa que cometeu o crime, afastando os conceitos de recuperação e ressocialização pretendidos pela pena, assim como os valores destacados pelos direitos humanos, que não faz distinção entre transgressor e um cidadão que não praticou o crime, seja ele do sexo masculino ou feminino.

Percebe-se que a Constituição Federal ao elencar os princípios fundamentais enumerou tal princípio afim de garantir um tratamento digno a todos os cidadãos detentores de direito, sejam eles crianças, adolescentes ou idosos. Essa garantia da qual dispõe o referido artigo, incumbe essa função de direitos e deveres não apenas para o Estado, mas também para a família e a sociedade.

\subsubsection{DIREITO PENAL E OS DIREITOS FUNDAMENTAIS DAS MULHERES PRESAS (DIREITOS FUNDAMENTAIS COM RELAÇÃO ÀS MULHERES)}

Primeiramente é necessário entender o Direito Penal em sua totalidade para posteriormente ligá-lo a mulher. Segundo Capez (2011, p. 19) “A missão do Direito Penal é proteger os valores fundamentais para a subsistência do corpo social, tais como a vida, a saúde, a liberdade, a propriedade, etc., denominados bens jurídicos." 
E o autor supracitado afirma ainda que:

O direito penal é o segmento do ordenamento jurídico que detém a função de selecionar os comportamentos humanos mais graves e perniciosos à coletividade, capazes de colocar em risco valores fundamentais para a convivência social, e descrevê-los como infrações penais, cominando,32o-lhes, em consequência, as respectivas sanções, além de estabelecer todas as regras complementares e gerais necessários à sua correta e justa aplicação. (CAPEZ, 2011, p.19)

De acordo com o supracitado o Direito Penal Simbólico que é aquele que de fato tem-se uma "fama" de conceber a rigorosidade e através deste fundamento acaba findando por ser ineficaz na prática. Trazendo triviais símbolos de inflexibilidades excessivas que decai no vazio.

Segundo Silveira (2007) no ano de 2005 houveram reformas no campo penal sexual ou direito penal de gênero, que suprimiu a expressão "mulher honesta". Essa expressão relata de modo inegável distinção entre homens e mulheres no que tange ao direito penal sexual frente à repressão criminal de condutas sexuais, considerado de modo diferente e subjetivo entre os gêneros.

Quanto a isso, Lima (2007) afirma:

Não faz muito tempo que o direito penal na obra de Lombroso intitulada "O homem delinquente" e "A mulher delinquente, a prostituta e a mulher normal" e em diversas outras obras, mencionava acerca de que na espécie humana a mulher atingia menor grau de evolução e também limitações físicas e mentais, como por exemplo, a limitada capacidade de amar e ser amada, crueldades relativas ao exercício da maternidade e afirmava que "a prostituição é para a mulher o que é o delito para o homem (LIMA, 2007, p. 318).

O Brasil atravessa por uma fase em que as Leis Penais de cunho representativo simbólico estão sendo elaboradas pelo legislador infraconstitucional. Tais Leis de acordo com Capez (2010, p. 19), "tem uma determinada carga moral forte e emocional, obtendo-se uma demonstração intenção pelo Governo tendo um legislador infundindo na sociedade".

Não foi de fato produzida ou estabelecida nenhuma inexistência a revolução real pelo Legislador. Decorre ou processar-se que a nova Lei, controla a violência contra as mulheres, transmitindo, conduzindo e preocupando-se em sanar ou remedias a vontade de um público eminente, que tem anseio, vontade e cobiça por Leis mais severas e benéficas a essa situação de cujo predominante na realidade do social e pena com mais rigor e severidade punitiva (GOMES, 2015).

Em 1980 esse acontecimento ganhou nitidez no meio social, por intermédio da organização política dos grupos feministas que começaram a reivindicar o reconhecimento dos direitos das mulheres e políticas públicas de justiça de gênero (ACOSTA, 2015). 
Em relação aos direitos fundamentais das mulheres presas, é bem complexo, a quantidade dos mesmos e há sempre uma busca efetiva para que sejam assegurados esses direitos para as mesmas. A mulher presa tem direito a assistência médica. O direito à saúde está incluso dentro do rol dos direitos fundamentais previsto na Constituição Federal (CF) de 1988, sendo reconhecido como o direito à vida. Inclusos na parte de saúde é uma grande luta hoje nas penitenciárias femininas os produtos básicos de higiene pessoal.

Segundo Lopes (2015) a mulher presa tem direito principalmente a integridade física e moral. Esses direitos estão garantidos na Constituição no artigo 5ㅇ, inciso XLIX. A Constituição de 1988 garante também no inciso III do artigo 5o: III que ninguém será submetido a tortura nem a tratamento desumano ou degradante. (BRASIL, 1988)

Ainda em relação a integridade física da mulher encarcerada é possível afirmar que se tornou inaceitável a tortura e Outros Tratamentos ou Penas Cruéis, Desumanos ou Degradantes, adotada pela Resolução 39/46, da Assembleia Geral das Nações Unidas, em 10 de dezembro de 1984 que designa tortura como sendo qualquer tipo de dor física ou mental. (ONU, 1984)

Lopes (2015) cita como exemplo de violação aos direitos da integridade física da mulher presa o fato de manter a mulher com algemas durante o seu parto. Isso é considerado uma prática errônea que enseja a responsabilização internacional do Brasil, sendo que é signatário das Regras Mínimas de Tratamento para as Mulheres Presas, conhecido como Regras de Bangkok, adotadas pela ONU em 2010. O documento conhecido por Regra de Bangkok veda explicitamente, na regra 24, o uso de qualquer meio indução de força antes, durante ou logo após o parto da mulher presa.

\subsection{OS TRATADOS INTERNACIONAIS E A REGRA DE BANGKOK}

Ramos (2012) afirma que não é mais aceitável que os Estados assumam compromissos internacionais e continuem permitindo atos de violações dos mesmos internamente, no caso dos tratados de proteção dos Direitos Humanos, é inaceitável que, após ratificar tratados de proteção destes direitos, o Estado continue a permitir violações aos Direitos Humanos, ou que postergue a criação de mecanismos para promover a proteção destes direitos.

Nota-se, portanto, que de forma geral, cada década que passa, por mais que seja gradativamente a mulher vem conquistando o seu lugar de direito e seus direitos de igualdade frente a sociedade, porém 
ainda há muitos direitos que necessitam ser reconhecidos e a luta e busca por esses direitos persistem a cada dia.

Em relação à proteção internacional da mulher tem inúmeros pactos, tratados, assim como declarações, convenções internacionais de proteção aos direitos humanos e planos de ação em seus textos preveem a proteção da mulher no sentido de eliminar discriminações. (BONINI, 2017)

Ainda de acordo com a mesma independe do fato das Declarações Internacionais e Planos de Ação das Conferências Internacionais não terem força de Lei igualmente aos tratados, convenções e pactos no ordenamento jurídico, deve-se levar em consideração como orientação a produção legislativa sendo imprescindível para igualdade de valores para as mulheres na sociedade atual.

As organizações internacionais podem ser divididas em três grupos segundo sua finalidade: organizações para fins específicos, que possuem um objetivo limitado a determinado assunto, como por exemplo a Comunidade Europeia do Carvão e do Aço; organizações regionais de fim amplo como a Organização dos Estados Americanos (OEA); e organizações de vocação universal, que pretendem englobar todos os Estados e assuntos de seus interesses, exemplo de organização de cunho universal é a Organização da Nações Unidas (Onu). (PIOVESAN, 2004)

Em relação às Leis do Brasil afirma-se maior favorância em relação a igualdade de direitos entre homens e mulheres, que se conquistou em num longo período massante na luta das mulheres pela ampliação de seus direitos, tendo forte influência o movimento feminista advindo desde os anos 70 que vem lutando pela igualdade de direitos entre homens e mulheres, pela eliminação de todas as formas de discriminação nas Leis e nas práticas sociais.

De acordo com Zaninelli (2015) as "Regras de Bangkok" são as diretrizes da ONU, de 2010, utilizadas para o tratamento de mulheres presas ou sujeitas a outras medidas privativas de liberdade. Essas regras merecem uma observação em conjunto com os desafios e as perspectivas para sua implantação no Brasil e no mundo.

Afirma ainda a supracitada que as Regras adotadas pelas Nações Unidas no tratamento de mulheres presas e medidas não privativas de liberdade para mulheres, também conhecidas como regras de Bangkok, são como um meio de proteção dada às mulheres em tempos de guerra e de paz produzido pela ONU. 
Esse documento importante é um conjunto de 70 regras, muitas de fácil e outras de difícil aplicação. Todavia, no Brasil não foi internalizada, sequer há tradução oficial, uma vez que a que se encontra disponível em nosso país foi traduzida pela pastoral carcerária de São Paulo.

De acordo com Conselho Nacional de Justiça em relação as Regras de Bangkok, as Regras das Nações Unidas para o tratamento de mulheres presas e medidas não privativas de liberdade para mulheres infratoras, dentre as mais relevantes podem ser citadas: quanto ao ingresso da mãe presa deve ser dada a atenção adequada e dedicada aos procedimentos de ingresso de mulheres e crianças, devido à sua especial vulnerabilidade nesse momento; em relação ao registro à identidade das crianças deverá ser confidencial e o uso de tais informações deverá sempre obedecer à exigência de garantir o melhor interesse das crianças; em relação a alocação das mesmas deverão permanecer, sempre que possível, em prisões perto do seu meio familiar ou local de reabilitação social. (BRASIL, 2016)

O supracitado afirma ainda que em relação à higiene pessoal e saúde, conforme brevemente abordado no tópico anterior deste estudo, as regras 5 a 9 garantem a acomodação de mulheres presas deverá conter instalações e materiais exigidos para satisfazer as necessidades de higiene específicas das mulheres. Quando ingressar na prisão a mulher deve fazer uma série de exames. É importante também atenção à saúde mental da mulher presa que são as regras 12 e 13. Já as regras 27 a 36 das Regras mínimas para o tratamento de reclusos, garantindo segurança e vigilância. As regras 37 a 39 garantem o contato com o mundo exterior, autorizando as presas a manterem comunicação com suas famílias. (CONSELHO NACIONAL DE JUSTIÇA: REGRA DE BANGKOK, 2016)

Além dessas regras o tratado traz: as regras sobre o Regime prisional; Relações sociais e assistência posterior ao encarceramento; Mulheres gestantes, com filhos/as e lactantes na prisão onde deverão receber orientação sobre dieta e saúde dentro de um programa a ser elaborado e supervisionado por um profissional da saúde qualificado; temos as regras aplicadas as presas Estrangeiras; Minorias e povos indígenas; Presas cautelarmente ou esperando julgamento e por fim as últimas regras sobre Pesquisa, planejamento e avaliação e Sensibilização pública, troca de informações e capacitação. (CONSELHO NACIONAL DE JUSTIÇA: REGRA DE BANGKOK, 2016)

O que os autores supracitados quiseram afirmar com suas conviç̧ões foi que sempre que uma atitude ou prática causar danos físicos e/ou psicológicos na mulher, e este dano, por consequência a levar a óbito, tal ato é caracterizado como sendo Feminicídio, qualquer ato violento é levado em consideração. 
O texto constitucional e a Lei de Execução Penal estão em total concordância com o estabelecido nas regras de Bangkok, todavia, quando é aplicada a prática, essas regras representam um ideal bem longe da realidade do sistema prisional brasileiro e sequer foram traduzidas oficialmente para o português. (ZANINELLI, 2015, p. 141)

Ou seja, a realidade da Lei da Execução Penal, está muito longe de ser perfeita. Ainda precisa de mudanças para proteger e dar abertura para a mulher ser mais reconhecida na sociedade, principalmente se tratando do sistema prisional onde é tão falha.

Por isso é tão importante aprofundar o estudo acerca da Execução Penal entendendo um pouco mais sobre a Lei da Execução Penal e os crimes de execução Penal no Brasil.

\section{OS CRIMES E EXECUÇÕES PENAIS NO BRASIL}

\subsection{LEI DE EXECUÇÃO PENAL}

Para iniciar essa discussão primeiramente tem-se a descrição de crime, dado que o tema central desta pesquisa se situa em torno da prisão de mulheres que cometem crimes, é importante dar ênfase, antes de prosseguir com a temática, ao conceito de crime, sabe-se que o conceito dado ao delito é puramente doutrinário, porque atualmente, não há no atual Código Penal um conceito exato de crime.

De acordo com Mendonça (2018): “O crime é espécie do gênero infração penal. ”

Art. 1 Considera-se crime a infração penal que a lei comina pena de reclusão ou de detenção, quer isoladamente, quer alternativa ou cumulativamente com a pena de multa; contravenção, a infração penal a que a lei comina, isoladamente, pena de prisão simples ou de multa, ou ambas, alternativa ou cumulativamente. (Lei de Introdução ao código penal 2018, p. 2)

Segundo o artigo elencado acima, percebe-se que a diferença está na pena. Em se tratando de penas privativas de liberdade, os crimes que são cometidos basicamente são punidos com reclusão ou detenção e, a contravenção penal com pena de prisão simples.

Afirma Mendonça (2018) que em relação ao conceito analítico de crime compreende-se a estrutura do delito. Isso significa que crime é composto por fato típico, ilícito e culpável. Sendo assim, afirma-se que predominantemente o conceito de crime é tripartite e envolve uma análise desses três elementos.

Dentro do fato típico é preciso analisar a conduta; nexo causal; resultado e se há previsão legal. Na ilicitude será verificado se o agente não atuou em: legitima defesa; estado de necessidade, estrito cumprimento do dever legal; exercício regular do direito ou consentimento do ofendido. Por fim, na culpabilidade, 
será analisada a imputabilidade; a potencial consciência da ilicitude; a exigibilidade de conduta diversa. (MENDONÇA, 2018, p.3)

Nucci (2009) relata que em relação ao conceito de crime a definição em si é artificial, isto é, independe de fatores naturais, constatados por um juízo de percepção sensorial, uma vez que se torna impossível classificar uma conduta, ontologicamente, como criminosa.

Já pela definição de Andreucci (2010, p. 71) o crime é definido sob o aspecto material (considerando o conteúdo do fato punível), sob o aspecto formal e sob o aspecto analítico. Conceito material de crime. Violação de um bem penalmente protegido. Conceito formal de crime. Conduta proibida por lei, com ameaça de pena criminal. Conceito analítico de crime: fato típico, antijurídico e culpável.

Greco (2012) entende que para se tenha cometido o crime o praticante do ato criminoso o fez de acordo com uma ação típica, ilícita e culpável. E ainda nos explana o seguinte conceito de forma mais detalhada para crime:

A função do conceito analítico é a de analisar todos os elementos ou características que integram o conceito de infração penal sem que com isso se queira fragmentá-lo. O crime é, certamente, um todo unitário e indivisível. Ou o agente comete o delito (fato típico, ilícito e culpável), ou o fato por ele praticado será considerado um indiferente penal. $O$ estudo estratificado ou analítico permite-nos, com clareza, verificar a existência ou não da infração penal; daí sua importância. (GRECO, 2012, p.142).

Na mesma consonância que o autor supracitado Capez (2012) relata que em relação ao crime: em primeiro lugar deve ser observada a tipicidade da conduta. Em caso positivo, e só neste caso, verificase se a mesma é ilícita ou não. Sendo o fato típico e ilícito, já surge a infração penal. A partir daí, é só verificar se o autor foi ou não culpado pela sua prática, isto é, se deve ou não sofrer um juízo de reprovação pelo crime que cometeu. Para a existência da infração penal, portanto, é preciso que o fato seja típico e ilícito.

Após entender o conceito de crime, é necessário relatar sobre a vigência da Lei de Execução Penal (Lei 7.210/84). De acordo com Marcão (2011) a Lei da Execução Penal tem mais de 40 anos desde 11 de julho de 1984.

A principal legislação aplicada ao cumprimento de pena em privação de liberdade é a Lei de Execução Penal (Lei 7.210/84).

De acordo com Castro (2015) para se ter o melhor entendimento da Lei de Execução Penal, é preciso que alguns conceitos sejam de antemão conhecidos. Primeiramente, é preciso saber que, dentro da 
esfera criminal, é possível que alguém seja preso de forma cautelosa, quando ainda não haja uma sentença condenatória transitada em julgado.

Ainda, afirma o supracitado, quando acontece esse caso, apesar de a pessoa ser considerada como sendo inocente, aliás, não foi condenada, a restrição de sua liberdade é essencial para a defesa de interesses maiores, como a ordem pública, na prisão preventiva. Por isso, fala-se em "cautela", sinônimo de cuidado. Há algo a ser preservado e o único meio de proteção é a prisão desse indivíduo, intitulado preso provisório.

São identificados como 3 os tipos de prisão cautelares: a prisão em flagrante, regulada nos artigos 301/310 do CPP, a prisão preventiva, prevista nos artigos 311/316, também do CPP, e por fim a prisão temporária, da Lei 7.960/89. (CASTRO, 2015)

O artigo 82, § 1 을 da Lei de Execução Penal assevera que as mulheres deverão ser recolhidas a estabelecimento prisional próprio, adequado à sua condição pessoal. $\mathrm{O}$ artigo 117, inciso III e V da Lei de Execuções Penais estabelece, ainda, que a progressão para o regime aberto, na modalidade de prisão de albergue domiciliar, somente poderá ser concedida a beneficiária condenada com filho menor ou deficiente físico ou mental, assim como a condenada gestante. (ESPINOZA, 2004)

A Lei de Execução Penal resguarda direitos à convivência das mulheres condenadas com seus filhos menores. Um deles está previsto no inciso III do artigo 117, garantindo à mulher condenada com filho menor ou deficiente físico ou mental a possibilidade de cumprimento da pena em regime aberto e em residência particular.

A Lei de Execução Penal assinala algumas peculiaridades que devem ser observadas nos estabelecimentos penais femininos, no intuito de que o direito à maternidade seja viabilizado a essas mulheres quando presas nessas prisões sob a responsabilidade do Estado brasileiro.

\subsection{OBJETO E A APLICAÇÃO DA LEI DE EXECUÇÃO PENAL}

De acordo com Carvalho (2014) a aplicação da execução penal, ou seja, o cumprimento da pena tem por objetivo, efetivar as disposições de sentença ou decisão criminal e proporcionar condições para harmônica integração social do condenado e do internado de volta a sociedade.

Toda a jurisdição penal dos juízes ou tribunais de justiça ordinária será exercida no processo de execução de acordo com a lei de Execução Penal e Código de Processo Penal. 
Segundo Nucci (2014) a execução penal um processo de natureza jurisdicional, onde o intuito é tornar efetiva a pretensão punitiva do Estado, envolvendo atividade administrativa.

Segundo Barreto (2019) estabelece o art. 10 da Lei de Execução Penal que "a execução penal tem por objetivo efetivar as disposições de sentença ou decisão criminal e proporcionar condições para a harmônica integração social do condenado e do internado".

Diante disso, entende-se que a execução penal pode ser compreendida como o conjunto de normas e princípios que tem como principal objetivo tornar convicto o comando judicial estipulando qual a sentença penal deve ser aplicada ao condenado (pena privativa de liberdade, pena restritiva de direitos ou multa) ou designa ao mesmo uma medida de segurança. (BARRETO, 2019)

Não se desconhece que a execução penal é atividade complicada, que se desenvolve, entrosadamente, nos planos jurisdicionais e administrativo. Também não se desconhece que essas atividades participam dois poderes estaduais: o Judiciário e o Executivo, por intermédio, respectivamente, dos órgãos jurisdicionais e dos estabelecimentos penais. (GRINOVER,1987, p.7)

Carvalho (2014) afirma ainda que o procedimento previsto na Lei de Execução Penal será judicial e se desenvolverá perante o juízo de Execução Penal.

Uma vez que, a lei não pode excluir da apreciação do Poder Judiciário lesão ou ameaça a direito.

Não configurando, portanto, pelo simples fato de ser uma causa de um juiz específico uma afronta ao princípio constitucional do juízo ou tribunal de exceção.

Isso implica também que, ninguém pode ser processado nem sentenciado senão pela autoridade competente, que no nosso caso, um Juiz da Vara de Execução Penal.

A execução penal quer punir a pessoa que cometeu o crime, condenando a viver com a sua penalidade, porém há uma classificação que busca assegurar qual o melhor lugar para a mãe presa cumprir a sua pena.

\subsection{CLASSIFICAÇÃO DOS CONDENADOS}

Orsolini (2015) afirma que a respeito da classificação dos apenados a pena privativa de liberdade é enxergada na atualidade como sendo uma ponderação inovadora da execução penal e transparece uma das mais adequadas novidades do sistema carcerário, visto que apresenta a reafirmação do princípio da individualização da pena e da assistência. 
A classificação dos condenados no penal inicia o seu trabalho por intermédio de todo um processo que irá determinar o sistema de laboração a que necessita ser dependente o apenado, disposição esta que pode ser obtida no ímpeto, ou seja, na decisão da unidade prisional, ou em outro, dividido principalmente para a triagem (ORSOLINI, 2003).

São utilizados métodos científicos de personalidade no procedimento de classificação, com a finalidade de observar o comportamento, e compreensão de todo discernimento da pessoa condenada em relação aos demais, dando a possibilidade da aplicação de experimentos, entre outros, "tudo com o sentido de tornar bem conhecida a individualidade do sentenciado e conferir-lhe o tratamento adequando, no presídio mais adequado" (MIRABETE, 2002, p. 52).

A classificação será feita por Comissão Técnica, a quem incumbirá elaborar o programa individualizador da pena privativa de liberdade adequada ao condenado ou preso provisório, como determina o art. 6․ Visando a obtenção dos elementos necessários a uma adequada classificação e com vistas à individualização da execução, nos termos do art. 8 da Lei de Execução Penal, o condenado ao cumprimento de pena privativa de liberdade em regime fechado ainda deverá ser submetido a exame criminológico, sendo o mesmo exame apenas facultativo para o condenado que tiver de iniciar o cumprimento da pena privativa de liberdade em regime semiaberto (MARCÃO, 2012. p. 44).

A classificação dos condenados é requisito essencial e primordial para definir o início da execução das penas privativas da liberdade e da medida de segurança da pessoa (MARCÃO, 2012).

Ainda segundo Marcão (2012) a classificação busca assegurar os princípios da personalidade e da proporcionalidade da pena, previstos no rol dos direitos e garantias previstos na Constituição. A classificação dos condenados sendo realizada da maneira como deve ser, cada sentenciado terá a compreensão acerca da sua personalidade e sua individualidade, e receberá o tratamento penitenciário específico, sendo atendido assim, o princípio da individualização da pena.

É imprescindível separar e classificar os presos, determinando o melhor lugar para que cumpram suas penas, de modo a evitar o contato negativo entre reincidentes e primários, pessoas com elevadas penas e outros, com penas brandas, dentre outros fatores. Em síntese, não se devem misturar, num mesmo espaço, condenados diferenciados (NUCCI, 2008, p. 408).

\subsection{ESTABELECIMENTOS PRISIONAIS E REGRAS ESTRUTURAIS}

De acordo com Andrade (2017) poucas são as disposições na Constituição e nas leis que possuem como objeto a execução penal imposta às mulheres. Pode citar no artigo 5으, inciso XLVIII da CF/88 que "a pena será cumprida em estabelecimentos distintos, de acordo com a natureza do delito, a idade e 
o sexo do apenado", que, como já demonstrado, não ocorre conforme estipulado, e já tinha sua previsão no Código Penal e na Lei de Execução Penal.

De acordo com o Princípio № 13, das políticas para mulheres todos os princípios e diretrizes propostos para o Modelo de Gestão da Política Prisional deverão ser assegurados para as mulheres em cumprimento de penas, encaminhadas para as alternativas penais ou egressas prisionais. "Deverão ser assegurados direitos e políticas para as mulheres encarceradas, de acordo com as especificidades de gênero, no tocante à arquitetura prisional e aos serviços penais voltados às áreas de cidadania, saúde, educação, trabalho, entre outras políticas. " (MELO, 2016, p.13)

Deve ser dada atenção especial à manutenção/recuperação de vínculo familiar, uso abusivo de drogas, saúde mental, cuidados na gestação e puerpério, incluindo a atenção aos filhos nascidos durante o cumprimento de pena e àqueles que, estando em ambiente extramuros, necessitem de um apoio maior das mães. Em hipótese alguma poderá ser permitido o abuso sexual das mulheres encarceradas por agentes estatais ou quaisquer outros sujeitos, sendo que os estabelecimentos penais femininos deverão assegurar que apenas a entrada de mulheres seja permitida nos espaços privativos das prisões. Também não será permitido o uso de algemas ou qualquer outro meio de contenção durante o parto e pós-parto das mulheres em situação de privação de liberdade. (MELO, 2016)

E ainda segundo Melo (2016):

De acordo com a diretriz no 34 deve-se evitar ao máximo a pena privativa de liberdade para mulheres gestantes, assegurando-lhes o direito aos exames de pré-natal e ao planejamento para o parto e acolhimento do bebê, bem como o convívio com o filho após o nascimento. $\mathrm{Na}$ inevitabilidade da privação de liberdade, os estabelecimentos prisionais femininos deverão garantir o direito ao adequado acompanhamento de pré-natal, ao parto seguro e ao convívio com o filho ou filha durante a fase de amamentação e período necessário à proteção infantil para viabilizar o princípio do interesse superior da criança. (MELO, 2016, p. 61)

Esses espaços devem ser adequados às práticas institucionais voltadas ao desenvolvimento integral da criança, coordenadas por equipe multidisciplinar, 62 contemplando atividades lúdicas e pedagógicas, fortalecimento do vínculo intrafamiliar e interface com as políticas públicas de saúde, de assistência social, de educação infantil e de convivência familiar e comunitária.

Todo o período de convívio da mãe com o filho será regido por planejamento institucional específico, acompanhado pela equipe multidisciplinar, que deverá elaborar relatório constando as diversas nuances e demandas desse público, incluindo as visitas próximas e frequentes e o convívio de familiares com o bebê. 
Devem ser realizados estudos sociais detalhados, para analisar as possibilidades de colocação das crianças que permanecem em ambiente intramuros em suas famílias extensas ou ampliadas, com a legalização de guarda temporária, até que a mãe cumpra sua pena. Tal intervenção deve ser priorizada, antes de qualquer ação, no sentido de inserir a criança em serviços de acolhimento ou propor família substituta.

Já na diretriz de no 39, é relatado que se deve ser dado cumprimento a todas as etapas necessárias para a garantia do direito à convivência familiar. Registra-se, nesse processo, a garantia para que a mãe presa seja ouvida em 63 audiência, na presença do Juiz, do Promotor de Justiça e Defensor Público, com defesa técnica efetiva, em casos de colocação do filho ou filha em família substituta ou destituição do poder familiar. (MELO, 2016)

Para finalizar esse tópico Andrade (2017) afirma que apesar da consciência das regras de disciplina e conduta das unidades prisionais, a mulher presa fica desamparada, não legalmente, mas negligenciada pelo Estado. Este desamparo surge desde o momento anterior a dosimetria de sua pena: começa pelo seu julgamento. Um julgamento que gera uma punição tripla: a punição pela conduta criminosa, a punição por ser mulher e não observar um comportamento machista que a sociedade impõe e por ser uma mãe que, apesar da maternidade, "escolheu" uma vida de crime. Isto não se caracteriza como justiça.

Em virtude desse julgamento que as mulheres presas sofrem, que deve ser compreendida a importância de trazer medidas que sanem esses problemas na prática.

\subsection{AS CELAS}

De acordo com Sousa (2019) está previsto nas normas brasileiras, tanto na Lei de Execução Penal, quanto na própria Constituição Federal, no que rege à execução penal, que as celas das mulheres presas devem ter, no mínimo, 6 metros quadrados, com uma ventilação adequada, janelas que facilitem o ambiente arejado, e devem ter o mínimo para realização da higiene pessoal e condições humanas de sobrevivência para as mulheres presentes e futuras encarceradas.

Segundo a afirmação de Santos, (2014, p. 9): “Na ausência desses locais, as mulheres eram colocadas juntamente com os homens ou ainda cumpriam pena em cadeias públicas ou celas adaptadas de presídios femininos." 
Mesmo o número de mulheres que cometem crimes sendo menores, as celas ainda são mais cheias do que nas prisões masculinas e talvez por isso não haja estímulos para que realizem a construção de unidades prisionais que atendam às necessidades do gênero feminino.

Conforme relata Zaninelli (2015) é real que as estruturas das celas são na maioria das prisões improvisadas. Deve ser levado em consideração o fato de que a grande maioria das unidades prisionais terem sido construídas para receber homens e somente depois serem usadas para unidades prisionais femininas.

Por isso as prisões não têm celas de espaço apropriado para a amamentação, berçário e creche, estrutura que necessária para o abrigo de mães e seus filhos que nascem sob a custódia do Estado e talvez por isso muitas mulheres busquem ter seus filhos e resolverem solicitar o regime especial para a prisão domiciliar.

\subsection{REGIME ESPECIAL: A PRISÃO DOMICILIAR}

Segundo Pereira (2018) o Egrégio Supremo Tribunal Federal conheceu do Habeas Corpus Coletivo no 143.641-SP, para conceder prisão domiciliar a mulheres condenadas por tráfico de drogas, que sejam mães de crianças ou que estejam na condição de gestante. A Lei de Execução Penal, em seu artigo 82, § 1으, com nova redação determinada pela Lei no 9.460, de 1997, determina cogentemente que a mulher e o maior de sessenta anos, separadamente, serão recolhidos a estabelecimento próprio e adequado à sua condição pessoal.

A Lei no 11.942, de 2009, mudou a Lei de Execução Penal, e em no artigo 83, definiu que os estabelecimentos penais destinados a mulheres serão dotados de berçário, onde as condenadas possam cuidar de seus filhos, inclusive amamentá-los, no mínimo, até 6 (seis) meses de idade. Em seguida, foi publicada a Lei no 12.121, de 2009, que previu a necessidade de os estabelecimentos penais de assistência a mulheres deverão possuir, exclusivamente, agentes do sexo feminino na segurança de suas dependências internas. (PEREIRA, 2018)

Segundo Távora e Alencar (2018), a prisão domiciliar é tida como medida cautelar de cerceamento da liberdade, dando lugar à prisão preventiva sempre que esta não seja recomendada em cadeia pública, quando se tratar de preso provisório, ou em prisão especial, para pessoas com prerrogativa de lei, por condições relacionadas à idade e à saúde do agente, particularizando assim as situações que requeiram o olhar humanitário à luz do princípio dignidade da pessoa humana. 
Segundo o CPP em seu Art. 318, IV, alterado pelo Estatuto da Primeira Infância, prevê a substituição da prisão preventiva pela prisão domiciliar quando o agente for gestante.

De acordo com Marcão (2017), a prisão domiciliar cumpre com a restrição da liberdade do apenado sem submetê-lo às mazelas do sistema carcerário, invoca questões humanitárias à luz do princípio da dignidade da pessoa humana e do direito à saúde, ao particularizar situações, contribui para a redução da população carcerária e, por conseguinte, gera economia ao erário público.

Uma condição que também está no Código de Processo Penal, que também foi alterada pelo Estatuto da Primeira Infância é para mulheres privadas de liberdade que têm filhos de até 12 anos incompletos. Neste aspecto, ressalta-se que a inovação trazida pelo referido Estatuto tem como foco garantir direitos das crianças.

Segundo Távora e Alencar (2018), a norma não exige que a mulher seja a única responsável pelos cuidados com o filho, como é exigido do homem. Todavia, exige-se comprovação de residência comum com filho de até 12 anos incompletos.

No contexto da prisão domiciliar, a publicada Lei no 13.769, de 19 de dezembro de 2018, veio pra trazer algumas alterações relevantes na legislação processual e de execução penal, bem como na Lei de Crimes Hediondos (Lei no 8.072/1990), ao passo que estabelece a substituição de prisão preventiva por prisão domiciliar para gestantes, mãe ou responsável por crianças ou pessoas com deficiência, além de disciplinar o regime de cumprimento de pena privativa de liberdade de condenadas na mesma situação. (MIRANDA, 2019)

\section{A MULHER MÃE NA EXECUÇÃO PENAL}

Neste tópico será mostrada a realidade da mulher, sendo mãe nas prisões, seus direitos, quais são os amparos para as mesmas dentro do sistema prisional de acordo com as Leis e os filhos no encarceramento e seus direitos. Por fim relata-se o habeas corpus coletivo e a diferença na progressão de regime.

\subsection{DIREITO A CELAS SEPARADAS}

Sabe-se que a grande maior parte dos presídios brasileiros possuem hoje problemas referentes à superlotação e condições precárias em relação às estruturais e de salubridade, não dando o mínimo de conforto e prezando por metade do bem-estar que as mesmas merecem como previsto na Lei. Em 
algumas cadeias as celas são improvisadas como enfermarias, dispondo de poucos equipamentos e profissionais qualificados.

De início pode-se citar o art. 8 da Lei no 8.069 de 13 de Julho de 1990. Nesse artigo pode ser destacado o fato de que é assegurado a todas as mulheres o acesso aos programas e às políticas de saúde da mulher e de planejamento reprodutivo e, às gestantes, nutrição adequada, atenção humanizada à gravidez, ao parto e ao puerpério e atendimento pré-natal, perinatal e pós-natal integral no âmbito do Sistema Único de Saúde, assim como também é assegurado as mulheres em cárcere o direito as celas separadas pós-parto.

O Legislador atenta para o filho da presa e assim prescreve o parágrafo $4^{\circ}$ do artigo 19 , § 4으, do ECA: Será garantida a convivência da criança e do adolescente com a mãe ou o pai privado de liberdade, por meio de visitas periódicas promovidas pelo responsável ou, nas hipóteses de acolhimento institucional, pela entidade responsável, independentemente de autorização judicial.

Conforme relata Armelin (2010) a grande maioria das mulheres encarceradas são mães, ou se tornam mães mesmo dentro da prisão. Grande parte dessas mulheres são consideradas a principal ou a única referência de cuidado dos filhos. Mesmo assim, essa realidade não é levada em consideração nem no momento da prisão quanto na sentença penal e, em grande parte, não há registro no inquérito policial ou processo-crime de que a mulher tem filhos ou citado sequer que está grávida.

Simões (2013) afirma que a mãe encarcerada tem o direito de estar com seu filho, não importa o crime que tenha cometido. A criança, em nenhum momento, poderá ser penalizada por algo que sua mãe tenha feito. Elas têm o direito ao convívio familiar e deve ter a chance de garantir o laço com sua mãe. É responsabilidade do Estado tutelar essa relação.

De acordo com Armelin (2010) é possível analisar que são poucos os estados brasileiros que disponibilizam ambientes adequados à essas mães presas com berçário ou creche para o cuidado das crianças dentro das penitenciárias, com as garantias que as mesmas merecem.

Não são todas instituições que dispõem desse ambiente, sendo pouquíssimas as que possuem um local adequado, apesar de ser um direito concedido pela lei à essas mães presas. Muitos dos filhos dividem as celas da prisão com a mãe, sem a mínima condição adequada para seu cuidado. 
$\mathrm{O}$ art. $83, \S 2 \circ$, da LEP dispõe que os estabelecimentos penais destinados às mulheres serão dotados de berçário, no qual as condenadas possam cuidar de seus filhos, inclusive amamentando-os, no mínimo, até os 06 (seis) meses de idade. Com o mesmo fim, está a previsão de que as penitenciárias femininas sejam dotadas de seção para gestante e parturiente, além de creche para abrigar crianças maiores de 06 (seis) meses e menores de 07 (sete) anos (art. 89 da LEP).

Diversas legislações brasileiras asseguram o direito de a mãe permanecer com seu filho na cadeia com as condições citadas acima sendo que na Constituição Federal é mencionado o fato de que será assegurada à mulher presa condições para que possam permanecer com seus filhos durante o período de amamentação nas celas com instalações especiais. (ARMELIN, 2010)

De acordo com a Lei da Execução Penal, Lei no 11.942, de 28 de maio de 2009, as mulheres mães presas têm o direito de cuidar e amamentar os filhos, no mínimo, até os seis meses de vida, com todos os seus direitos assegurados. Além do mais, as prisões femininas precisam propiciar locais especiais, tais como: seções para gestantes ou parturientes e creche para as crianças de seis meses até sete anos (caso esta esteja desamparada).

A importância do vínculo entre mãe e bebê na fase inicial da vida é um dos principais motivos pelos quais a permanência da criança na penitenciária é, de certo modo, defendida.

Kurowsky (1990) afirma que as celas separadas de alojamento para mãe e filhos dentro da prisão surgiu com o intuito de que as mães pudessem permanecer com seus filhos durante o período da amamentação dos mesmos, visto que é uma fase de extrema importância no desenvolvimento dos filhos, se não a mais importante. Para mais, muitos dos filhos das apenadas encontravam-se em estado de abandono.

Por isso para finalizar este tópico, de acordo com as afirmações de Armelin (2010) é preciso entender que é necessário um novo olhar para a realidade das mulheres encarceradas e, sobretudo, para as mães que estão presas.

É preciso entender que o direito da mãe presa, impacta diretamente também do direito fundamental da criança à convivência familiar e de ser cuidada por sua família de origem, sendo a mãe o principal vínculo afetivo na vida dessas crianças.

\subsection{CRECHES E ESTRUTURAS}

Coisas que a lei exige estão longe de serem atendidas. Além da falta do convívio com a família, as crianças crescem em meio à falta de creches, berçários, ambiente para brincar e cuidado médico. 0 
ambiente da prisão já é inadequado para uma criança nascer e passar seus primeiros dias de vida, mais ainda se não possuir infraestrutura adequada. (NANA, 2017)

A LEP relata claramente no artigo 89 que, além dos requisitos referidos no artigo 88, a penitenciária de mulheres será dotada de seção para gestante e parturiente e de creche para abrigar crianças maiores de 06 (seis) meses e menores de 07 (sete) anos, com intuito de assistir a criança desamparada cuja responsável estiver presa.

Apesar do nome, a galeria "creche" nas prisões é um ambiente muito divergente de uma creche real, pois esta última se caracteriza por ser "um ambiente especialmente criado para oferecer condições ótimas, que propiciem e estimulem o desenvolvimento integral e harmonioso da criança sadia nos seus primeiros quatro anos de idade". (RIZZO, 1991, p.23 apud SANTANA, 1998, p.43).

A função da galeria creche é alojar as mães com os seus filhos, até que estes completem três anos de idade. Também é um local diferente de uma creche tradicional, pois as crianças passam o dia todo com suas mães, não possuindo cuidadores terceirizados ou treinados para o zelo infantil. (ARMELIN, 2010)

O supracitado afirma ainda em se tratando das prisões que:

Em se tratando das prisões com berçários, é possível afirmar que as minorias das prisões femininas possuem berçários ou estruturas separadas das galerias prisionais. As mães passam, em grande parte dos casos, o período integral com os filhos. A minoria dessas mães presas permanece no local durante o dia e retornam para as celas durante a noite em companhia de seu filho. Uma parcela mínima das mães presas permanece no local durante o dia e retornam para as celas sem a companhia da criança. (ARMELIN, MELLO; GAUER, ARQUIVO DIGITAL, p. 7, 8)

Em relação as celas nas prisões é preciso entender, segundo Machado (2016), que para abrigar a criança nos estabelecimentos prisionais femininos pelo tempo permitido pela legislação, os mesmos devem garantir a existência de centro de referência materno infantil os berçários, dormitórios para mães e bebês, banheiros que comportem banheiras infantis, brinquedotecas, áreas de lazer com espaço descoberto e creches, enfatizando que todos estes devem estar devidamente adequados as diretrizes básicas para arquitetura penal previstas pelo Ministério da Justiça, garantindo uma vida de qualidade tanto para a mãe presa quando para a criança. 


\subsection{FILHOS E O ENCARCERAMENTO: DIREITO DA MATERNIDADE À MULHER ENCARCERADA}

Muitas das presas já entram na prisão gestantes, outras engravidam dentro da prisão, mesmo com todo o cuidado dos sistemas prisionais para tentar evitar o fato.

Em primeiro lugar é preciso entender que o fato de a criança ficar presa com a mãe nos primeiros meses de vida é considerado um avanço, uma conquista, voltada para assegurar a proximidade entre mãe e filho. (PAGNOZZI, 2018)

Segundo o artigo 37 do Código Penal, "as mulheres cumprem pena em estabelecimento próprio, observando-se os deveres e direitos inerentes à sua condição pessoal". A pessoa presa tem privado o direito à liberdade, contudo é seu direito receber um tratamento digno e humano como determina o artigo 10, do Pacto Internacional sobre Direitos Civis e Políticos (PLANALTO,2014).

A Lei de Execução Penal prevê acompanhamento médico à mulher, "principalmente no pré-natal e no pós-parto, extensivo ao recém-nascido", entre outras determinações que não estão sendo seguidas pelo sistema penitenciário. (CASADO e CASIAN, 2018)

As normas regulamentares na prisão para mulheres, principalmente as que são mães em cárcere, têm de ser tais que a dignidade humana delas seja em tudo respeitada, e que "na sua condição de pessoas, sujeitos de direito, de deveres e de responsabilidade, sejam contemplados os direitos e deveres próprios da mulher" (MIOTTO, 1992, p.124).

Stella (2009, p. 294), afirma que ao longo do tempo, o "papel outorgado às mulheres em nossa sociedade é o de serem as primeiras e principais guardiãs das crianças".

Então, para as mães presas a sociedade, o direito e o afeto da família continua a responsabilidade pelos cuidados de suas crianças pequenas.

A prisão feminina, segundo a Defensoria (2015) tem algumas especificidades, se comparada com a masculina, a saber: o direito de ter um estabelecimento próprio; ter respeitados seus direitos e deveres referentes à sua condição de mulher; o direito de estar com seus filhos durante o período de amamentação.

A partir dessas diferenças, a Defensoria Pública do Estado de São Paulo emitiu uma cartilha direcionada à mulher presa, para que se tome conhecimento de seus direito e deveres para assegurar o direito da mulher/mãe encarcerada. Para Santana (1998), esse ambiente real deve oferecer um trabalho multidisciplinar com atividades psicopedagógicas, além de oferecer estimulação, 
alimentação adequada e assistência à saúde, para que assim a criança possa desenvolver todas suas capacidades.

Entendo o supracitado, sabe-se que os presídios devem oferecer a mulher encarcerada todo um tratamento especializado, com profissionais aptos para auxiliá-la na função maternidade dentro das prisões.

Viofore (2005, p. 99) lembra que a "prisão é fator emocional de constante estresse na vida de qualquer detenta". Contudo o estresse aumenta se com aos problemas prisionais são acrescentados os da gravidez, da amamentação e dos cuidados com um filho pequeno. Seja pelo ambiente de convivência da prisão ou pela estrutura precária.

A proximidade entre mãe e filho acaba trazendo reflexos na vida dos inocentes presos, que, em meio ao ambiente da prisão, sem berço, sem banheiro adequado e sem cozinha com higiene, as crianças crescem longe dos olhos da sociedade.

Para NANA (2017) "é fácil esquecer que mulheres são mulheres sob a desculpa que todos os criminosos devem ser tratados de maneira idêntica". Porém, a mesma afirma que "a igualdade é desigual quando se esquecem as diferenças" (NANA, 2017, p. 19). Então, mesmo na prisão, as mulheres não podem ser tratadas do mesmo jeito que os homens.

Entretanto é bom destacar que a falta de estrutura das prisões e as condições em que as mães ficam está longe de ser ideal para a saúde, crescimento e educação das crianças. Domingues et al. (2018), entende que há diferentes tipos de presas que se tornam mães dentro da penitenciária. Temos a jovem que comete delito, sem ter consciência de que está grávida.

Quando a mulher é condenada, passa todo o período gestacional dentro da prisão. Há aquelas que, mesmo estando grávidas, cometem delito. Existem também mulheres que, enquanto aguardam julgamento em cadeias mistas, têm relações sexuais e engravidam. Outras engravidam durante a visita íntima e sabe-se ainda das que vão para a prisão, deixando seus filhos sob os cuidados de familiares. Segundo afirma Viafiore (2005, p. 93), mesmo na "história da estruturação do sistema prisional brasileiro, não houve uma preocupação com a mulher criminosa e nem com a família".

Andrade (2017) afirma ainda que para as mulheres incorporadas ao sistema prisional, a gravidez é motivo muito além de felicidade, medo e alterações hormonais: é lidar com o fato de dar à luz na prisão. É lidar com os problemas de qualquer outra presidiária, mas pensando em outra vida além de sua própria. 
Segundo o Departamento penitenciário nacional diretoria de políticas penitenciárias coordenação de políticas para as mulheres e promoção das diversidades (2016) entre as diversas problemáticas que assolam a convivência temporária da mãe com seu filho ou filha, em ambiente prisional, está o processo de separação que, em geral, não ocorre de forma gradual e com base na análise do caso em concreto, levando-se em consideração o superior interesse da criança.

Caso haja bebês nascidos antes do aprisionamento da mulher é facultado a permanência na unidade prisional, desde que estejam em período de amamentação ou que necessitem de cuidados específicos da genitora.

Para tanto, estes estabelecimentos deverão ser dotados de áreas específicas para as mulheres gestantes, lactantes e mães em período de convivência com seus filhos, incluindo nestes locais a existência de berçários, unidades materno-infantis ou outras estruturas apropriadas com desenvolvimento de serviços penais diferenciados para tal especificidade.

De acordo com Mello e Gauer (2011) companhia do filho durante o aprisionamento é percebida como um aspecto positivo, o qual a mulher projeta no filho a minimização das dificuldades enfrentadas durante este período.

Os filhos de mães presas enfrentam situações difíceis que aprofundam gravemente essa condição existencial. No município de Itumbiara existe um projeto idealizado e coordenado pelo juiz Fernando Augusto Chacha de Rezende, onde trata exatamente desse amparo as mães encarceradas.

Desde o ano de 2016, o projeto visa proteger e amparar integralmente os filhos de mães reeducandas. O município de Itumbiara foi a décima primeira comarca a receber o programa. O juiz da 1a Vara Cível e da Infância e da Juventude de Itumbiara, Silvio Jacinto Pereira foi o responsável pela execução desse projeto. Projetos assim tem custo zero para o judiciário. (MINISTÉRIO PÚBLICO DO ESTADO DE GOIÁS, 2016)

Projetos como este deveriam ser exemplo no Brasil inteiro, para amparar as mães presas dando a chance de conviverem com seus filhos dando apoio aos mesmos assegurando o direito a uma vida digna, tanto dentro, como fora da prisão sendo uma forma alternativa da mãe se relacionar com seu filho mesmo estando presa.

A mãe presa e seu filho têm, portanto, direitos que lhe assegurem uma vida digna diante das situações em que se encontram, através de Resoluções, Portarias, Estatuto, Código Penal, Constituição Federal, entre outros dispositivos legais. (DOMINGUES et al., 2018) 
Quando averiguado e relatado que não existem condições de medidas alternativas e sendo obrigado à prisão da mulher deve-se aplicar as Regras de Bangkok. O Brasil assinou as Regras de Bangkok que se preocupa com o tratamento de mulheres presas e orienta medidas privativas de liberdade no caso das mulheres infratoras. (BRASIL, 2016)

Vislumbrando a efetivação de tais direitos das crianças e adolescentes,
imprescindível é a atuação interdisciplinar entre os entes públicos, cabendo ao
Estado principalmente promover, constantemente, a execução de políticas
públicas eficazes, capazes de propiciar o pleno desenvolvimento de toda a
população, principalmente no que tange a crianças e adolescentes. Ou seja, no
caso das mães presidiárias, o Estado desenvolve duplo papel, uma vez que
possui sob sua égide a tutela dos presídios, e, ainda, é responsável pela
proteção e preservação dos vínculos familiares, assegurando a crianças e
adolescentes o direito à convivência familiar e comunitária. (ALENCASTRO,
2015, p.7) Segundo Domingues et al. (2018), é de responsabilidade do Estado em proteger a criança do sistema penitenciário e, ao mesmo tempo, dar a mãe presa melhores condições de vida dentro do cárcere. Diante das leituras, constatamos que, apesar de existirem políticas públicas para garantir os direitos das mães e das crianças, há pouquíssima atenção quanto ao cumprimento desses direitos. Há muito a ser feito por parte do Estado, quanto à indução social e psicoafetiva da criança.

De acordo com Alencastro (2015) sabe-se que além dos deveres das encarceradas também tem os direitos das mesmas, incluindo os seus filhos que desde que mesmo antes de nascerem já são protegidos por seus direitos. Incluso no título VIII "Da ordem Social”, Capítulo VII "Da Família, da Criança, do Adolescente, do Jovem e do Idoso", o art. 227, da Constituição Federal de 1988, 3 trata do direito à convivência familiar, sendo esse um direito fundamental de ordem social.

Pinho (2007) afirma que os direitos de ordem social ganharam especial relevância na Constituição Federal de 1988 visto que corresponde a uma prestação positiva do Estado em prol da sociedade. Em vigência hoje no Brasil está a Constituição de 1988 que é a norma suprema do ordenamento jurídico dentro de nosso país, e, sabido é que em tal documento estão resguardados os direitos fundamentais de cada indivíduo, sendo tais direitos o núcleo da proteção da dignidade da pessoa humana.

O princípio da dignidade da pessoa humana está previsto no artigo $1^{\circ}$, inciso III, da Constituição Federal. “A República Federativa do Brasil, formada pela união indissolúvel dos Estados e Municípios e do Distrito Federal, constitui-se em Estado Democrático de Direito e tem como fundamentos: III- A dignidade da pessoa humana". (CONSTITUIÇÃO FEDERAL, 1988).

A Constituição Federal dispõe em seu artigo 227, caput, que: 
Art. 227- É dever da família, da sociedade e do Estado assegurar à criança, ao adolescente e ao jovem, com absoluta prioridade, o direito à vida, à saúde, à alimentação, à educação, ao lazer, à profissionalização, à cultura, à dignidade, ao respeito, à liberdade e à convivência familiar e comunitária, além de colocalos a salvo de toda forma de negligência, discriminação, exploração, violência, crueldade e opressão. (CONSTITUIÇÃO FEDERAL, 1988).

Ainda conforme previsão legal, o Estatuto da Criança e do Adolescente no artigo 15, vem reforçar os direitos já conferidos pela Constituição Federal, inerentes à pessoa da criança e do adolescente, de modo, que o princípio da dignidade da pessoa humana, segundo este dispositivo supralegal é considerado a base da entidade familiar, além de validar a garantia de qualquer violação desta.

Desta forma, a dignidade da pessoa humana é um direito inviolável que no âmbito familiar deve ser efetivado pela própria família, pela sociedade e pelo Estado, para que as crianças e os adolescentes possam ter o mínimo de dignidade assegurada. Ou seja, é conferido a estes o dever de respeitar e proteger os direitos fundamentais dessas pessoas destinatárias de tutela especial. "A família, base da sociedade, tem especial proteção do Estado" (CONSTITUIÇÃO FEDERAL, 1988. Art.226)

O princípio da Dignidade da Pessoa Humana representa o epicentro axiológico da ordem constitucional, irradiando efeitos sobre todo o ordenamento jurídico, não apenas no que tange aos atos e às situações envolvendo a esfera pública dos atos estatais, mas também todo o conjunto das relações privadas que se verificam no âmbito da sociedade. No âmbito do planejamento familiar, o princípio em tela deve não somente ser aplicado no sentido de garantir o exercício desse direito pelo casal, como também na proteção daquele que poderá vir a nascer, e o conflito entre essas duas perspectivas deve ser solucionado, em regra, em favor desse último (GAMA, 2008).

O Estatuto da Criança e do Adolescente tem por objetivo a proteção integral destes. Conforme dispõe o artigo. $1^{\circ}$ do referido estatuto: Esta lei dispõe sobre proteção integral à criança e ao adolescente. Desta forma, crianças e adolescentes são sujeitos que gozam de direitos plenos. Ou seja, são direitos especiais e específicos, pela condição de serem pessoas em desenvolvimento, estes que ainda nem vivem sua vida com plenitude, gozam de mais direitos que qualquer outro cidadão, ou seja, devem ser muito mais protegidos, pois são detentores de tutela especial “A proteção integral da criança e do adolescente, objetiva assegurar-Ihes seu pleno desenvolvimento, seu crescimento, o cumprimento de suas potencialidades e tornar-se cidadãos adultos livres e dignos". (CURY, 2008 p.36). 
A proteção integral tem como fundamento a concepção de que crianças e adolescentes são sujeitos de direitos, frente à família, à sociedade e ao Estado. Rompe com a ideia de que sejam simples objetos de intervenção no mundo adulto, colocando-os como titulares de direitos comuns a toda e qualquer pessoa, bem como de direitos especiais decorrentes da condição peculiar de pessoas em processo de desenvolvimento. (RÊGO, 2017. Apud. p. 10)

$\mathrm{O}$ art. 3o do ECA ainda determina que a criança e o adolescente gozam de todos os direitos fundamentais inerentes à pessoa humana, sem prejuízo da proteção integral de que trata essa lei, assegurando-Ihes, por lei ou por outros meios, todas as oportunidades e facilidades, a fim de lhes facultar o desenvolvimento físico, mental, moral, espiritual e social, em condições de liberdade e de dignidade.

O princípio do melhor interesse estende-se a todas as relações jurídicas envolvendo os direitos das crianças e adolescentes. Assim, o art. 1으, do ECA, estabelece a proteção integral à criança e ao adolescente, a quem são assegurados todos os direitos fundamentais da pessoa humana independentemente da situação familiar, conforme dispõe o art. 3ำ do ECA que determina: a criança e o adolescente gozam de todos os direitos fundamentais inerentes à pessoa humana, sem prejuízo da proteção integral de que trata essa lei, assegurando-lhes, por lei ou por outros meios, todas as oportunidades e facilidades, a fim de lhes facultar o desenvolvimento físico, mental, moral, espiritual e social, em condições de liberdade e de dignidade.

O princípio do melhor interesse da criança visa garantir os direitos inerentes a pessoa do menor, resultado de uma mudança da própria concepção de família como ambiente norteador de desenvolvimento de seus integrantes. Com isso, para impedir os abusos de poder pelas partes mais fortes da relação, ainda que sejam eles os pais, tal princípio tem por base a invulnerabilidade da criança no âmbito familiar. Como percebemos, o Estatuto da Criança e do Adolescente aborda a questão da proteção de seus interesses como prioridade absoluta. Às crianças e os adolescentes passaram a ser sujeitos e detentores de direitos, tendo em vista a sua vulnerabilidade e a necessidade de cuidados e proteção especial. Tornando esses interesses de caráter imprescindíveis antes mesmos que tais direitos sejam concretizados.

Percebe-se que a Constituição Federal ao elencar os princípios fundamentais enumerou tal princípio afim de garantir um tratamento digno a todos os cidadãos detentores de direito, sejam eles crianças, adolescentes ou idosos. Essa garantia da qual dispõe o referido artigo, incumbe essa função de direitos e deveres não apenas para o Estado, mas também para a família e a sociedade. Conclui-se que, as referidas leis garantam e promovam a dignidade da pessoa humana, assegurando seus direitos e 
cumprimento de seus deveres, cabendo ao Estado o dever de positivar e efetivar as medidas necessárias para o eficaz cumprimento de tais direitos, e reprimir todo ato contrário à dignidade da pessoa humana.

\title{
4.3 HABEAS CORPUS COLETIVO
}

O Habeas Corpus coletivo $n^{\circ} 143.641$ foi impetrado perante o Supremo Tribunal Federal, em maio de 2017, de relatoria do ministro Ricardo Lewandowski, pelo Coletivo de Advogados em Direitos Humanos (CADHU) com pedido de medida liminar, "[...] em favor de todas as mulheres presas preventivamente que ostentem a condição de gestantes, de puérperas ou de mães de crianças sob sua responsabilidade, bem como em nome das próprias crianças" (STF, 2018, p. 4)

No dia 20 de fevereiro de 2018 foi julgado o Habeas Corpus coletivo. Confira-se o trecho do voto do relator:

\begin{abstract}
Em face de todo o exposto, concedo a ordem para determinar a substituição da prisão preventiva pela domiciliar - sem prejuízo da aplicação concomitante das medidas alternativas previstas no art. 319 do CPP - de todas as mulheres presas, gestantes, puérperas ou mães de crianças e deficientes, nos termos do art. 2o do ECA e da Convenção sobre Direitos das Pessoas com Deficiências [...], relacionadas neste processo pelo DEPEN e outras autoridades estaduais, enquanto perdurar tal condição, excetuados os casos de crimes praticados por elas mediante violência ou grave ameaça, contra seus descendentes ou, ainda, em situações excepcionalíssimas, as quais deverão ser devidamente fundamentadas pelo juízes que denegarem o benefício. Estendo a ordem, de ofício, às demais as mulheres presas, gestantes, puérperas ou mães de crianças e de pessoas com deficiência, bem assim às adolescentes sujeitas a medidas socioeducativas em idêntica situação no território nacional [...]. (grifo nosso). (STF, Habeas Corpus no 143.641/SP, Relator: Ministro Ricardo Lewandowski, 170 Data de Julgamento: 20/02/2018, Segunda Turma, Data da Publicação: 09/10/2018).
\end{abstract}

De acordo com Moura et al. (2019) a decisão do Habeas Corpus coletivo no 143.641 é um marco histórico na evolução no próprio instituto do Habeas Corpus, visto que reconhece o seu cabimento, e possibilita o seu alcance a uma massa, ainda que não identificada, mas identificável e que está sujeita a constrangimento provocado por juízes singulares e tribunais de variadas instâncias. No dia 19 de dezembro de 2018, foi promulgada a Lei no 13.769/2018, em que o legislador positivou na legislação processual penal, pelo menos em parte, o teor da decisão tomada no Habeas Corpus coletivo no 143.641. 
Sarmento (2015) afirma que diante da inexistência ou insuficiência de procedimento idôneo a tutelar determinado direito material, o juiz deve extrair das regras processuais existentes a sua máxima potencialidade, a fim de permitir a proteção mais adequada possível.

Assim, para cada tipo de violação ao direito à liberdade ambulatorial, deve corresponder uma tutela jurisdicional adequada. Daí porque se pode afirmar que o instrumento processual do habeas corpus deve ter amplitude correspondente às situações de ofensa ou de ameaça à liberdade de ir e vir sobre as quais pretende incidir.

Se a ofensa à liberdade for meramente individual, a impetração de habeas corpus individual será suficiente. No entanto, para ofensas ao direito de locomoção que apresentarem perfil coletivo, o ajuizamento de habeas corpus coletivo é a providência que mais realiza o direito à efetiva tutela jurisdicional.

Importante salientar também que de acordo com Grillo (2017) os juízes que julgam as mães presas podem conceder-lhes, de ofício, tornozoleira eletrônica para as mães com filhos menores. Está previsto na interpretação conjunta dos artigos 318 do Código de Processo Penal e 116 da Lei de Execuções Penais.

Mas é importante salientar que ainda de acordo com supracitado esse tipo de medida não é obrigatório para todos os casos julgados, mas salienta que decisões garantindo a concessão da tornozeleira não significam impunidade, mas a execução da pena mais proporcional.

\subsection{A DIFERENÇA NA PROGRESSÃO DE REGIME}

Segundo o Direito Penal (2009) a definição de progressão de regime é a transferência do condenado do regime mais gravoso a outro menos severo, quando este demonstrar condições de adaptação ao regime prisional mais suave.

De acordo com o artigo 112, da LEP, a pena privativa de liberdade será executada em forma progressiva com a transferência para regime menos rigoroso, a ser determinada pelo juiz, quando o preso tiver cumprido ao menos um sexto da pena no regime anterior e ostentar bom comportamento carcerário, comprovado pelo diretor do estabelecimento, respeitadas as normas que vedam a progressão. 
0 art. 112, que trata da progressão de regime, passa a contar com o § 3o para disciplinar de forma específica a progressão da mulher gestante, mãe ou responsável por crianças ou pessoas com deficiência. Neste caso, são requisitos cumulativos para a progressão: I - não ter cometido crime com violência ou grave ameaça a pessoa; II - não ter cometido o crime contra seu filho ou dependente; III - ter cumprido ao menos $1 / 8$ (um oitavo) da pena no regime anterior; IV - ser primária e ter bom comportamento carcerário, comprovado pelo diretor do estabelecimento; $V$ - não ter integrado organização criminosa. (BOLETIM CRIMINAL, 2019, p. 6)

Segundo Alvino (2018) se essa mulher preencher esses requisitos acima poderá ter sua progressão de regime, independente se ele seja comum ou hediondo, pela fração de 1/8 (um oitavo da pena), e não mais $1 / 6$ para os crimes comuns ou $2 / 5$, ré primária ou $3 / 5$, ré reincidente para os crimes hediondos.

O artigo 112, § 4ํ, da LEP, apenas faz uma ressalva, que em caso de cometimento de novo crime doloso ou prática de falta grave isso implicará: na regressão de regime (art. 118 , I, da LEP); e na impossibilidade de se beneficiar dos requisitos favorecidos do § 3으, do artigo 112 da LEP.

A Lei no 13.769/2018 acrescentou o inciso VII ao art. 72 da LEP, para dizer que o Departamento Penitenciário Nacional deverá:

VII - acompanhar a execução da pena das mulheres beneficiadas pela progressão especial de que trata o § 3 ㅇ do art. 112 desta Lei, monitorando sua integração social e a ocorrência de reincidência, específica ou não, mediante a realização de avaliações periódicas e de estatísticas criminais.

Os requisitos para que a pessoa tenha direito à progressão de regime estão previstos na Lei no 7.210/84 (Lei de Execução Penal - LEP) e também no Código Penal. No Brasil, apesar de ter-se descrito na lei a forma que deve ocorrer a progressão de regime, na prática muitas coisas ocorrem de maneira diferente. (NUCCl, 2017)

Portanto pode-se entender em relação a isso que de com o artigo 112, da LEP, a pena privativa de liberdade será executada em forma progressiva com a transferência para regime menos rigoroso, a ser determinada pelo juiz, quando o preso tiver cumprido ao menos um sexto da pena no regime anterior e ostentar bom comportamento carcerário, comprovado pelo diretor do estabelecimento, respeitadas as normas que vedam a progressão.

\section{CONSIDERAÇÕES FINAIS}

O estudo relatou em seu primeiro tópico a luta pelo direito da mãe presa e a evolução das conquistas das mesmas na Constituição. O Estado tem e terá sempre a função de combater as desigualdades, e o 
Estado fará isso com determinadas políticas que irão levar como principal forma as especialidades de todos os grupos sociais que são diferentes entre si.

Mesmo que não seja totalmente colocado em prática, os avanços ao longo do tempo são perceptíveis, tendo uma mudança radical na forma como juridicamente as mulheres são vistas, pois antes da Constituição, as mulheres estavam em uma posição inferior aos homens, ficando sempre "escondidas" pela falta de seus direitos. Também foi explanado um breve resumo sobre as Regras de Bangkok apresentando as principais e mais relevantes.

Conclui-se neste capítulo que, as referidas Leis de direito dos direitos humanos e fundamentais garantam e promovam a dignidade da pessoa humana, assegurando seus direitos e cumprimento de seus deveres, cabendo ao Estado o dever de positivar e efetivar as medidas necessárias para o eficaz cumprimento de tais direitos, e reprimir todo ato contrário à dignidade da pessoa humana.

No segundo tópico relataram-se sobre os crimes e execução penal no Brasil, onde relata que a Lei de Execução Penal demonstra algumas peculiaridades que devem ser observadas nos estabelecimentos penais femininos, no intuito de que o direito à maternidade.

Não se pode sair dessa forma para observação, de que para se ter totalmente a defesa do direito da mãe presa, para que seja feita uma sociedade totalmente e verdadeiramente igualitária, que seja para precaver o bem-estar e a liberdade de todos, é imprescindível que seja o principal foco da sociedade, observar as necessidades específicas de todos os diferentes grupos de mulheres e principalmente das mulheres encarceradas.

No terceiro e último capítulo é relatado à mulher mãe na execução penal. Fica evidente que as mães têm direito as celas separadas, e a mais conforto dentro do sistema prisional. Além disso, as prisões têm que dispor de creches ou espaços que visem o bem-estar de seus filhos nascidos dentro da prisão. Também ficou claro a questão do pedido de Habeas Corpus em favor de todas as mulheres presas preventivamente que ostentam a condição de gestantes, de puerperais ou de mães de crianças sob sua responsabilidade.

Por fim foi explanada a progressão de regime das presas. Fica claro que a progressão de regime é aquela que pode ser aplicada nos casos de regime mais gravoso a outro menos punitivo, quando a presa demonstrar condições de adaptação ao regime prisional mais suave, mas cada caso é um caso e deve-se analisar. 
Em relação ao problema concluiu-se que por mais que existam Leis não se consegue efetivar e resguardar todo os direitos que são garantidos para as mães presas. É preciso entender que a situação desses filhos do cárcere merece mais atenção onde o Estado deve colocar em prática os estabelecimentos da Lei, para dar as condições mínimas e adequadas às mães e seus filhos dentro do cárcere.

Devem ser não só criadas Leis mas sim aplicadas. Ou devem ser criados projetos alternativos que assegurem o bem estar dessas mães nas instalações, como o projeto do município de Itumbiara Amparando Filhos onde as mães tem o direito de estar presente na vida dessas crianças mesmo estando presas. O fato é que as mulheres cobrem mais os seus direitos como fizeram desde o início advindo da Revolução Industrial que foi onde começaram a conquistar o seu espaço na sociedade.

Portanto, é preciso entender que a situação desses filhos do cárcere merece mais atenção onde o Estado deve colocar em prática os estabelecimentos da Lei, para dar as condições adequadas as mães e seus filhos dentro do cárcere. 


\section{REFERÊNCIAS}

ARMELIN, B. D. F. Filhos do cárcere: estudo sobre as mães que vivem com seus filhos em regime fechado. Revista Da Graduação. 2010. Disponível em:

https://revistaseletronicas.pucrs.br/index.php/graduacao/article/view/7901. Acesso em 21 de outubro de 2020.

ANDREUCCI, Ricardo Antonio. Manual de Direito Penal. 6. ed. rev. e atual. São Paulo: Saraiva, 2010.

ALONSO, Miguel Ángel Garita. Uma Visão do Estado Contemporâneo. Cultura Jurídica, Facultad de Derecho, México, 2011. Disponível em:

<http://www.derecho.unam.mx/investigacion/publicaciones/revista- cultura/pdf/CJ(Art_17).pdf>. Acesso em 12 de Set de 2020.

BASTOS, Athenas. Direitos e garantias fundamentais: o que são e quais as particularidades? 2018. Disponível em:< https://blog.sajadv.com.br/direitos-e-garantias-fundamentais/> Acesso em 21 de Outubro de 2020.

BIJOS, Leila. Promessas de empoderamento para mulheres. In: Revista de Informação Legislativa, ano 43, n. 169. Brasília: Senado Federal. 2006.

BOBBIO, Norberto, MATTEUCCI, Nicola et PASQUINO, Gianfranco. Dicionário De Política. Fundação Universidade De Brasília. Editora Universidade De Brasília, 11a edição, 1998.

BONINI, Luci. Feminicídio. Breve reflexão acerca da proteção às mulheres no Brasil. 2017. Artigo, JusBrasil. Disponível em: https://lucibonini5.jusbrasil.com.br/artigos/380546103/Feminicídio. Acesso em 12 de Set de 2020.

BRASIL. Decreto-Lei N. 2.848, de 7 de Dezembro de 1940. Código Penal Brasileiro. Disponível em <http://www.planalto.gov.br/ccivil_03/decreto-lei/del2848.htm>. Acesso em 12 de Set de 2020.

BRASIL. Constituição da República Federativa do Brasil, 1988.

BRASIL. Lei no 7210, de 11 de julho de 1984. Lei de Execução Penal.

BRASIL. Conselho Nacional de Justiça. Regras de Bangkok: Regras das Nações Unidas para o Tratamento de Mulheres Presas e Medidas Não Privativas de Liberdade para Mulheres Infratoras, Departamento de Monitoramento e Fiscalização do Sistema Carcerário e do Sistema de Execução de Medidas Socioeducativas, Conselho Nacional de Justiça - 1. Ed - Brasília: Conselho Nacional de Justiça, 2016. 80 p. Livro digital Disponível em:

http://www.cnj.jus.br/files/conteudo/arquivo/2016/03/a858777191da58180724ad5caafa6086.pdf; Acesso em 21 de outubro de 2020.

CASADO, Letícia e CASIAN, Natália. Gestantes e mães de crianças de até 12 anos podem cumprir prisão domiciliar. Disponível em: https://www1.folha.uol.com.br/cotidiano/2018/02/stf-concede-habeascorpus-coletivo-a-gestantes-e-maes-de-criancas-ate-12-anos.shtml; Acesso em 21 de outubro de 2020. 
CAPEZ, Fernando. Curso de Direito Penal: Parte Geral. 15a Ed. São Paulo: Saraiva, v. 1, 2011. Acesso em: 20 de abr. de 2017.

CARVALHO. Augusto da Silva. Do objeto e da aplicação da lei de execução penal. 2014. Disponível em: https://www.recantodasletras.com.br/textosjuridicos/4990411. Acesso em 12 de Set de 2020.

COELHO, Renata. A evolução da cidadania da Mulher Brasileira. Artigo. 2017. Disponível em: http://www.mpf.mp.br/pgr/documentos/Evoluojurdicadacidadaniadamulherbrasileira_RenataCoelh o.pdf. Acesso em 20 de Set de 2020.

CURY, Munir. Estatuto da Criança e do Adolescente comentado: comentários jurídicos e sociais. 9.ed. São Paulo: Malheiros, 2008.

DALARI, Dalmo de Abreu. Elementos de teoria geral do estado. Editora Saraiva. 2a edição. 1998.

DEFENSORIA. Disponível em:

< https://www.defensoria.sp.def.br/dpesp/Repositorio/41/Documentos/cartilha-mulher-presa.pdf> Acesso em: 26 de outubro. 2020.

ESPINOZA, Olga. A mulher encarcerada em face do poder punitivo. São Paulo. IBCCRIM, 2004

GAMA. Guilherme Calmon Nogueira da. Princípios Constitucionais de Direito de Família; Guarda Compartilhada a Luz da Lei no 11.698/08; Família, Criança, Adolescente e Idoso. 1. Ed. São Paulo. Editora Atlas, 2008.

GAYÓN, Mariana Berlanga. “Feminicídio”: Fazendo Gênero 9: Diásporas,Diversidades, Deslocamentos. 2010.

GOMES, I. S. Feminicídios e possíveis respostas penais: dialogando com o feminismo e o direito penal. Gênero \& Direito, Periódico do Núcleo de Estudos e Pesquisas sobre Gênero e Direito Centro de Ciências Jurídicas, João Pessoa, 2015.

GRECO, Rogério. Curso de Direito Penal. 11. ed. Rio de Janeiro: Impetus, 2009.

GRILLO, Brenno. Prisão domiciliar de ofício para mãe presa ainda é exceção no país. Execução Penal. Disponível em: https://www.conjur.com.br/2017-out-08/prisao-domiciliar-oficio-mae-presa-aindaexcecao-pais. Acesso em 08 de novembro de 2020.

KUROWSKI, Cristina Maria. Análise crítica quanto a aspectos de implantação e funcionamento de uma creche em penitenciária feminina. Porto Alegre, 1990.

LIMA, Paulo Marco Ferreira. A mulher delinquente: algumas perguntas e algumas conclusões. InMulher e direito penal. Rio de Janeiro: Forense, 2007.

MACHADO, Juliana Dantas. Maternidade encarcerada: uma análise da substituição da prisão preventiva pela domiciliar das mulheres gestantes e com filhos menores de 12 anos no Tribunal de Justiça do Estado do Rio de Janeiro. Rio de Janeiro. 2016.

MELO, Felipe Athayde Lins de. Modelo de Gestão para a Política Prisional. Brasília. 2016 
MELLO, Daniela Canazaro e GAUER, Gabriel. Vivências da maternidade em uma prisão feminina do Estado do Rio Grande do Sul. In: Saúde \& Transformação social, Florianópolis. 2011.Disponível em: http://stat.saudeetransformacao.incubadora.ufsc.br/index.php/saudeetransformacao/article/view/6 54/876. Acesso em 21 de outubro de 2020.

MIOTTO, Armida Bergamini. Assistência às presas. Revista de Informação Legislativa, v. 29, n. 116. Brasília: Senado Federal, outubro/dezembro, 1992

NANA, Queiroz. Presos que mestruam: a brutal vida das mulheres - tratadas como homens - nas prisões brasileiras. Rio de Janeiro: Record, 2017.

MIRANDA. Margarida Araújo Barbosa. O direito à prisão domiciliar para reeducandas gestantes e mães com filhos menores de 12 anos, sob a perspectiva do princípio da dignidade da pessoa humana. 2019. Disponível em: http://www.conteudojuridico.com.br/consulta/Artigos/52939/o-direito-a-prisaodomiciliar-para-reeducandas-gestantes-e-maes-com-filhos-menores-de-12-anos-sob-a-perspectivado-principio-da-dignidade-da-pessoa-humana. Acesso em: 01 de outubro de 2020.

MENDONÇA, Ana Cristina. Penal Prática. Editora JusPODIVM. 2018.

MORAES, Alexandre de. Direito Constitucional. São Paulo: Atlas, 2006

MOURA, Gina; ROCHA, Jorge Bheron; LANDIM, Maria Noêmia. Tribuna da Defensoria: indeferimentos de prisão domiciliar devem ser revistos. 2019. Disponível em: https://www.conjur.com.br/2019-jan01/indeferimentos--prisao-domiciliar-revistos-lei. Acesso em 22 de outubro de 2020.

NARVAZ, Martha Giudice. KOLLER, Sílvia Helena. Famílias e patriarcado: da prescrição normativa à subversão criativa. Psicologia \& Sociedade. 2006. Disponível em:

https://www.scielo.br/pdf/psoc/v18n1/a07v18n1.pdf. Acesso em 01 de outubro de 2020.

NUCCl, Guilherme de Souza. Manual de direito penal: parte geral: parte especial. 6. ed. rev., atual. e ampl. São Paulo: Revista dos tribunais, 2009.

NUCCl, Guilherme de Souza. Código Penal Comentado. 18 ed. rev., atual. e ampl. - Rio de Janeiro: Forense, 2017.

PAGNOZZI, Bárbara C. Mães Condenadas, filhos prisioneiros. 2018. Disponível em:

<https://jus.com.br/artigos/67095/maes-condenadas-filhos-prisioneiros/2> Acesso em 22 de outubro de 2020.

PIEROBOM, Thiago André de Ávila et al. Modelos europeus de enfrentamento à violência de gênero: experiências e representações sociais. Brasília: ESMPU, 2014.

PINHO, de Leda. A mulher no direito romano: noções históricas acerca de seu papel na constituição da entidade familiar. Revista Jurídica Cesumar. 2002.

PLANALTO. Disponível em: < http://www.planalto.gov.br/ccivil_03/decreto/1990- 1994/D0592.htm> Acesso em 22 de outubro de 2020. 
RAMOS, André de Carvalho. Responsabilidade internacional do estado por violação de direitos humanos. Revista CEJ, América do Norte, 2012. Disponível em:

<http://www.jf.jus.br/ojs2/index.php/revcej/article/view/663/843>. Acesso em 12 de Set de 2020.

RODRIGUEZ, Annelise Siqueira Costa. Feminicídio no Brasil: uma reflexão sobre o direito penal como instrumento de combate à violência de gênero. Monografia. 2016.

SANTOS, Silvana Mara de Morais dos. OLIVEIRA, Leidiane. Igualdade nas relações de gênero na sociedade do capital: limites, contradições e avanços. Rev. Katál. Florianópolis v. 13. 2010.

SANTANA, Judith Sena da Silva. A creche sob a ótica da criança. Feira de Santana: UEFS, 1998.

SARLET, Ingo Wolgang. Dignidade e direitos fundamentais na Constituição Federal de 1988. Porto Alegre: Livraria do Advogado, 2001.

SARMENTO, Daniel; BORGES, Ademar; GOMES, Camilla. O cabimento do habeas corpus coletivo na ordem constitucional brasileira. Rio de Janeiro: Clínica de Direitos Fundamentais da Faculdade de Direito da UERJ, UERJ Direitos, 2015, p.21. Disponível em:

<http://uerjdireitos.com.br/wpcontent/uploads/2015/05/uerjdireitos_habeas-corpus-coletivo-eliberdade-re-8558101.pdf>. Acesso em 22 de outubro de 2020.

SIMÕES, Vanessa Fusco Nogueira. Filhos do Cárcere: Limites e possibilidades de garantir os direitos fundamentais dos filhos das mulheres privadas de liberdade no Brasil. Porto Alegre: Núria Fabris Ed., 2013.

SILVEIRA, Renato de Mello Jorge. Direito penal sexual ou direito penal de gênero?. In Mulher e direito penal. Rio de Janeiro: Forense, 2007.

SCHMIDT, Andrei Zenkner. Direitos, Deveres e Disciplina na Execução Penal. In: CARVALHO, Salo de (Org.). Crítica à execução penal. Rio de janeiro: Lúmen Júris, 2007.

SODER, José. Direitos do homem. São Paulo: Companhia Editora Nacional, 1960.

TAVASSI, Ana Paula Chudzinski; MORAIS, Pâmela. Inciso I - Igualdade De Gênero. "Homens e mulheres são iguais em direitos e obrigações, nos termos desta Constituição. 2019. Disponível em: https://www.politize.com.br/artigo-5/igualdade-de-genero/ Acesso em 29 de Outubro de 2020.

TÁVORA, N; ALENCAR, R.R. Curso de Direito Processual Penal. 13. ed. Salvador: JusPodium, 2018.

VIAFORE, Daniele. A Gravidez no Cárcere Brasileiro: Uma Análise da Penitenciária Feminina Madre Pelletier. Publicado na Revista de Direito da PUCRS. Direito \& Justiça, ano XXVI, 2005. Disponível em: http://revistaseletronicas.pucrs.br/ojs/index.php/fadir/article/view/571. Acesso em 22 de outubro de 2020.

ZANINELLI, Giovana. Mulheres encarceradas: Dignidade da pessoa humana, gênero, legislação e políticas públicas. Dissertação apresentada ao Programa de Mestrado em Ciências Jurídicas da UENP: Jacarezinho, 2015. 